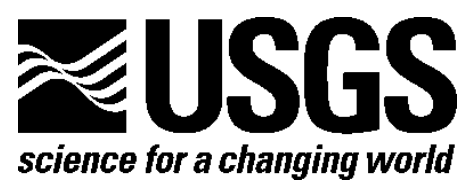

\title{
Altered Hydrologic and Geomorphic Processes and Bottomland Hardwood Plant Communities of the Lower White River Basin
}

By Sammy L. King, Richard F. Keim, Cliff R. Hupp, Brandon L. Edwards, Whitney A. Kroschel, Erin L. Johnson, and J. Wes Cochran

Open-File Report 2016-1113

U.S. Department of the Interior U.S. Geological Survey 


\title{
U.S. Department of the Interior
}

SALLY JEWELL, Secretary

\section{U.S. Geological Survey}

\author{
Suzette M. Kimball, Director
}

U.S. Geological Survey, Reston, Virginia: 2016

\begin{abstract}
For more information on the USGS—-the Federal source for science about the Earth, its natural and living resources, natural hazards, and the environment-visit http://www.usgs.gov/ or call 1-888-ASK-USGS (1-888-275-8747).

For an overview of USGS information products, including maps, imagery, and publications, visit http://store.usgs.gov.
\end{abstract}

Any use of trade, firm, or product names is for descriptive purposes only and does not imply endorsement by the U.S. Government.

Although this information product, for the most part, is in the public domain, it also may contain copyrighted materials as noted in the text. Permission to reproduce copyrighted items must be secured from the copyright owner.

Suggested citation:

King, S.L., Keim, R.F., Hupp, C.R., Edwards, B.L., Kroschel, W.A., Johnson, E.L., and Cochran, J.W., 2016, Altered hydrologic and geomorphic processes and bottomland hardwood plant communities of the lower White River Basin: U.S. Geological Survey Open-File Report 2016-1113, 32 p., http://dx.doi.org/10.3133/ofr20161113.

ISSN 2331-1258 (online) 


\section{Contents}

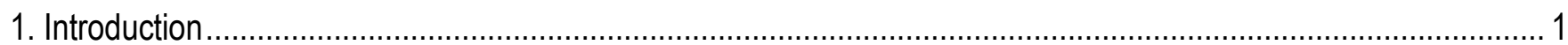

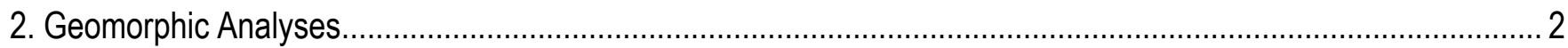

2.1 Historic and Current Rates of Bank Erosion and Channel migration ........................................................ 2

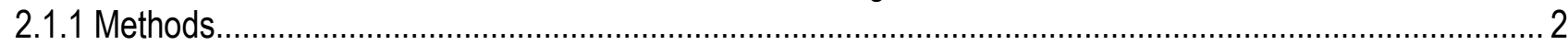

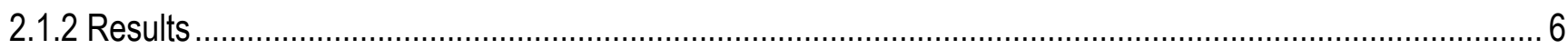

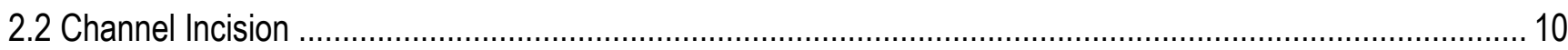

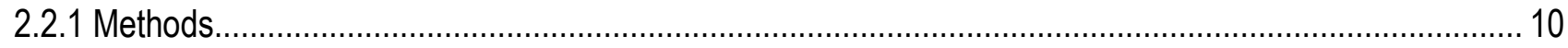

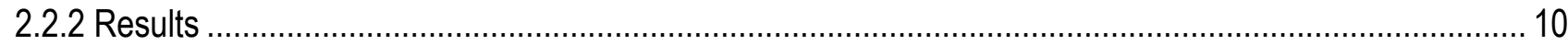

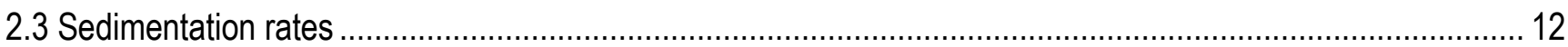

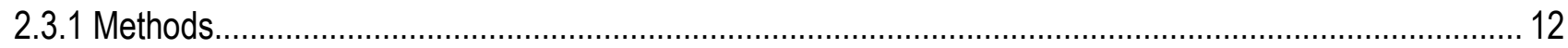

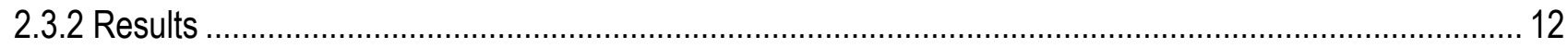

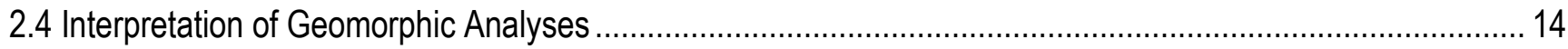

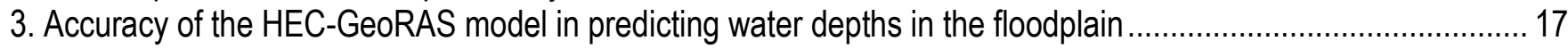

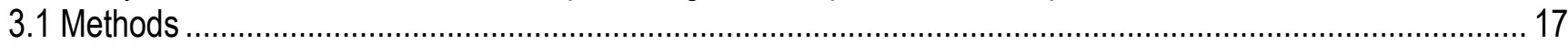

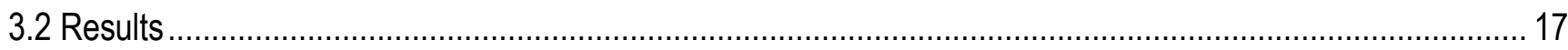

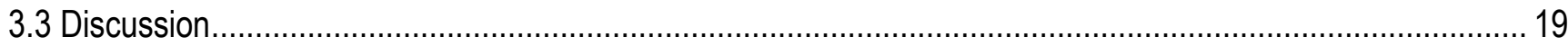

4. Stand establishment patterns of bottomland hardwoods within selected plant communities ............................... 20

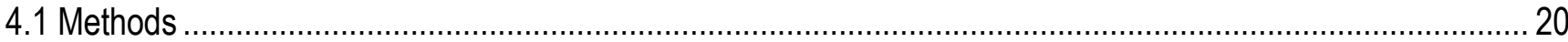

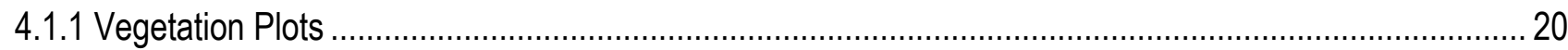

4.1.2 Stand Development-Tree Ring Analysis ...................................................................................... 21

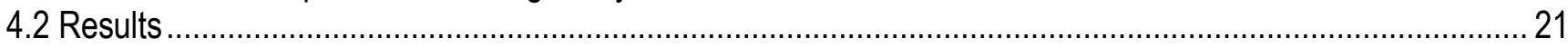

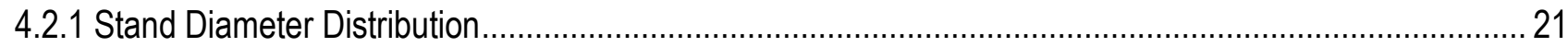

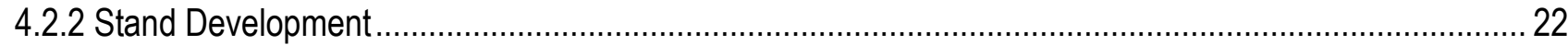

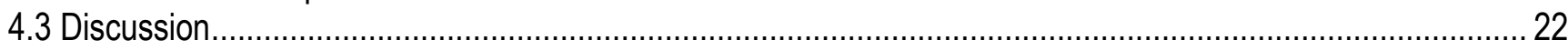

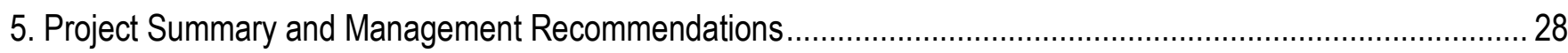

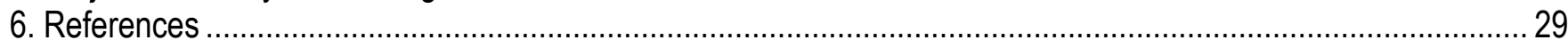

\section{Figures}

2.1. Location map of sediment pad and bank retreat measurement sites...................................................... 4

2.2. Field crew conducting bank retreat measurement .......................................................................... 5

2.3. Channel migration rates between DeValls Bluff and the Norrell lock ....................................................

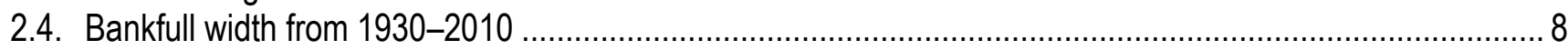

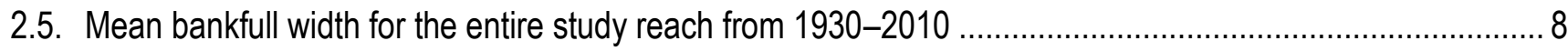

2.6. Amount of bank retreat for sites near Clarendon, St. Charles, and Jacks Bay ......................................... 9

2.7. Bank height above water surface on the lower White River on 21-23 August 2014 ................................. 11

2.8. Bed elevation from 2013 thalweg survey ................................................................................... 11

2.9. Sediment deposition rates on lower White River ……….................................................................. 13

2.10. Deposition rates integrated over first 500 miles of transects extrapolated to 5 -year total deposition versus along-stream distance and relative local bank height.............................................................. 16

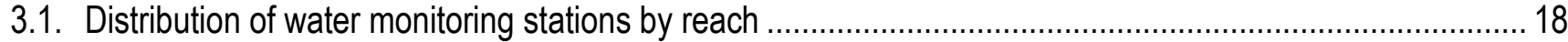

3.2. Observed floodplain depths compared to modeled floodplain depths at 28 well monitoring stations by reach.

4.1. Number of trees per acre in each approximate 2.0 inch-diameter class for common bottomland hardwood species along three reaches of the White River floodplain. 
4.2. Establishment dates of common bottomland hardwood trees cored within the Clarendon reach .................25

4.3. Establishment dates of common bottomland hardwood trees cored within the St. Charles reach ................ 26

4.4. Establishment dates of common bottomland hardwood trees cored within the Jacks Bay reach .................22

\section{Tables}

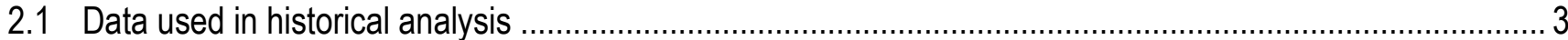

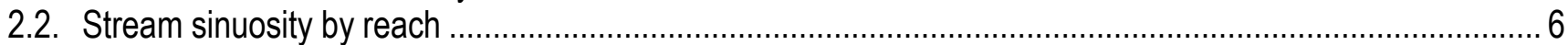

4.1. Total basal area and stem density of most common species within three designated reaches of the White River floodplain

\section{Conversion Factors}

Inch/Pound to International System of Units

\begin{tabular}{lcl}
\hline & Multiply & \multicolumn{1}{c}{ Bo obtain } \\
\hline inch (in.) & Length & \\
foot (ft) & 2.54 & centimeter $(\mathrm{cm})$ \\
mile (mi) & 0.3048 & meter $(\mathrm{m})$ \\
\hline & 1.609 & kilometer $(\mathrm{km})$ \\
\hline acre & Area & \\
square foot $\left(\mathrm{ft}^{2}\right)$ & 0.4047 & hectare $(\mathrm{ha})$ \\
square foot per acre $\left(\mathrm{ft}^{2} / \mathrm{ac}\right)$ & 0.09290 & square meter $\left(\mathrm{m}^{2}\right)$ \\
\hline & 0.229568 & square meter per hectare $\left(\mathrm{m}^{2} / \mathrm{ha}\right)$ \\
\hline cubic foot $\left(\mathrm{ft}^{3}\right)$ & Volume & \\
cubic foot $\left(\mathrm{ft}^{3}\right)$ & 0.02832 & cubic meter $\left(\mathrm{m}^{3}\right)$ \\
& 0.02832 & cubic meter $\left(\mathrm{m}^{3}\right)$ \\
\hline foot per year $(\mathrm{ft} / \mathrm{yr})$ & Flow rate & \\
inch per year $(\mathrm{in} / \mathrm{yr})$ & 0.3048 & meter per year $(\mathrm{m} / \mathrm{yr})$ \\
square foot $\left(\mathrm{ft}^{2}\right)$ & 25.4 & millimeter per year $(\mathrm{mm} / \mathrm{yr})$ \\
\hline
\end{tabular}

International System of Units to Inch/Pound

\begin{tabular}{lcl}
\hline & Length & \\
\hline meter $(\mathrm{m})$ & 3.281 & foot $(\mathrm{ft})$ \\
\hline & Area & \\
\hline hectare $(\mathrm{ha})$ & 2.471 & acre \\
\hline
\end{tabular}




\section{Datum}

Horizontal coordinate information is referenced to the North American Datum of 1983 (NAD 83).

\section{Abbreviations}

$\begin{array}{ll}\text { A } & \text { area of migration polygon } \\ \text { ac } & \text { acre } \\ \text { c } & \text { circa } \\ \text { CAAQ } & \text { Carya aquatica } \\ \text { CELA } & \text { Celtis laevigata } \\ \text { Dbh } & \text { diameter-at-breast height } \\ \text { DEM } & \text { digital elevation model } \\ \text { DOQQ } & \text { digital ortho quarter quad } \\ \text { FIA } & \text { Forest Inventory and Analysis } \\ \text { FRPE } & \text { Fraxinus pennsylvanica } \\ \mathrm{ft} & \text { feet } \\ \text { ft/yr } & \text { feet per year } \\ \mathrm{ft}{ }^{2} / \mathrm{ac} & \text { square feet per acre } \\ \text { GIS } & \text { geographic information system } \\ \text { ha } & \text { hectare } \\ \text { LMAV } & \text { Lower Mississippi Alluvial Valley } \\ \text { m } & \text { meters } \\ \text { M } & \text { channel migration rate } \\ \text { mi } & \text { miles } \\ \text { NHAP } & \text { National High Altitude Photography } \\ \text { P } & \text { perimeter of migration polygon } \\ \text { PNV } & \text { potential natural vegetation } \\ \text { QULY } & \text { Quercus lyrata } \\ \text { QUTE } & \text { Quercus texana } \\ \text { RMSE } & \text { root mean square error } \\ \text { stems/ac } & \text { stems per acre } \\ \text { ULAM } & \text { Ulmus americana } \\ \text { USACE } & \text { U.S. Army Corps of Engineers } \\ \text { USGS } & \text { U.S. Geological Survey } \\ \text { yr } & \text { year } \\ & \end{array}$




\title{
Altered Hydrologic and Geomorphic Processes and Bottomland Hardwood Plant Communities of the Lower White River Basin
}

\author{
By Sammy L. King, ${ }^{1}$ Richard F. Keim, ${ }^{2}$ Cliff R. Hupp, ${ }^{3}$ Brandon L. Edwards, ${ }^{2}$ Whitney A. Kroschel, ${ }^{2}$ \\ Erin L. Johnson, ${ }^{2}$ and J. Wes Cochran²
}

\section{Introduction}

The lower White River, Arkansas, is a Ramsar Convention Wetland of International Importance that supports the second largest tract of bottomland hardwood forests in North America. The vegetation and hydrology relationships on the White River have generated a lot of scientific interest. In the late 1990s, managers observed substantial headcutting of White River tributaries and the mass wasting of banks, leading to speculation that the White River was geomorphically unstable and threatening the ecological integrity of the floodplain forest.

Numerous modifications within the watershed, and within the larger Lower Mississippi Alluvial Valley (LMAV) have led to changes in the lower White River. Most notably, channel training of the Mississippi River (Biedenharn and Watson, 1997) has lowered base level for the White River, and a series of flood control dams upstream have significantly altered flow (Craig and others, 2001). A lowered base level increases hydraulic gradient, which can result in increases in sinuosity via meandering, channel incision, or bank widening (Nanson and Huang, 2008), depending on geomorphic constraints (Simon and Rinaldi, 2006). Flow regulation often results in reduced peak stages, flood frequency, duration of overbank flooding and sediment load (Williams and Wolman, 1984), and commonly causes subsequent channel degradation downstream of dams (as in Phillips and others, 2005; Hupp and others, 2009a).

Rivers and their floodplains are process-response systems whose geomorphic state is the result of geologic setting and hydrologic drivers (Nanson and Croke, 1992; Phillips, 2010). Significant changes to the gradient, hydrology, or sediment load result in adjustment toward a new quasi-equilibrium condition (as in Knox, 2006; Hupp and others, 2009a; Hupp and others, 2015). Geomorphic adjustment at the reach and regional scale can trigger substantial changes to river-floodplain interactions and feedback mechanisms between geomorphic, hydrologic, and ecological processes (as with Hupp, 1992; Ligon and others, 1995; Knox, 2006; Hupp and others, 2009b; Osterkamp and Hupp, 2010).

The White River and its floodplain support the second largest floodplain forest in North America, and changes in the frequency and duration of flooding or groundwater processes have implications for floodplain ecology. Tree species composition and productivity of these floodplain forests are a function of surface and subsurface hydrologic regime (Klimas, 2009, Gee and others, 2015; Allen and others, 2016).

\footnotetext{
${ }^{1}$ U.S. Geological Survey, Louisiana Cooperative Fish and Wildlife Research Unit, School of Renewable Natural Resources, Louisiana State University.

${ }^{2}$ School of Renewable Natural Resources, Louisiana State University.

${ }^{3}$ U.S. Geological Survey.
} 
Bank widening and incision can lower the water table and alter flood frequency and associated nutrient and sediment flows to the floodplain community (as with Hupp and others, 2009a; Schenck and Hupp, 2009; Hupp and others, 2015). An understanding of the relationships among present and future (predicted) geomorphic processes, surface and subsurface hydrologic processes, and tree growth and establishment is critical for evaluating the effects of future development activities within the White River watershed.

The work explained in this report was conducted to assess geomorphic adjustment of the lower White River to hydrologic modifications and establish forest age and community structure within selected communities within the floodplain. Also, the HEC-GeoRAS model was evaluated for predicting flood depth and duration within the floodplain. Hydrologic modeling using HEC-GeoRAS is a common way to model flooding in a floodplain. A parameterized model exists for the White River based on observed flows at gauges, but its ability to reproduce current and future hydrological conditions throughout the floodplain has not been quantified. The objectives of this work are to-

1. Identify current and historical rates of bank erosion and channel migration.

2. Determine bank heights and channel incision along the river from Norrell lock to DeValls Bluff.

3. Determine sedimentation rates along three sections of the floodplain (as in the Clarendon area, near St. Charles, and near Jacks Bay).

4. Evaluate the accuracy of the HEC-GeoRAS model in predicting water depths in the floodplain.

5. Determine stand establishment patterns of bottomland hardwoods within selected plant communities along three sections of the floodplain.

This study provides baseline information on the current geomorphic and hydrologic conditions of the river and can assist in the interpretation of forest responses to past hydrologic and geomorphic processes. Understanding the implications for floodplain forests of geomorphic adjustment in the LMAV is key to managing the region's valuable resources for a sustainable future.

\section{Geomorphic Analyses}

\subsection{Current and Historical Rates of Bank Erosion and Channel Migration}

\subsubsection{Methods}

To determine current and historical rates of bank erosion and meandering, we analyzed channel planform using topographic maps and aerial photography to document geomorphic trends from c. 1929-2010 on the lower White River from DeValls Bluff to Norrell Lock and Dam (fig 2.1, table 2.1). The exact starting year of the study period is indeterminate; data used to produce U.S. Geological Survey (USGS) topographic maps published in 1939-1941 are listed as collected from 1929-1941. We chose 1930 as the estimated start date because the majority of data collection dates listed for each map began in 1930. Airphoto mosaics were used for 1950 data, National High Altitude Photography (NHAP) images were used for 1984 data, and Digital Ortho Quarter Quad (DOQQ) imagery was used for 2001 and 2010 data. Topographic maps and the 1950 and 1984 datasets were georeferenced to 2010 DOQQ before analysis. 
Table 2.1 Data used in historical analysis.

\begin{tabular}{|c|c|c|c|c|}
\hline Document Type & $\begin{array}{c}\text { Data Acquisition } \\
\text { Date }\end{array}$ & Publication Date & $\begin{array}{c}\text { Scale or } \\
\text { Resolution }\end{array}$ & Source \\
\hline $\begin{array}{l}\text { USGS topographic map } \\
\text { series }\end{array}$ & $1929-1939$ & 1939,1940 & $1: 62,500$ & $\begin{array}{l}\text { Mississippi River } \\
\text { Commission }\end{array}$ \\
\hline Air photo index mosaic & 1950 & & 6 meters & $\begin{array}{l}\text { Dale Bumpers White River } \\
\text { National Wildlife Refuge }\end{array}$ \\
\hline $\begin{array}{l}\text { USGS topographic map } \\
\text { series }\end{array}$ & 1964,1965 & 1967,1968 & $1: 24,000$ & US Geological Survey \\
\hline NHAP & 1984 & 1984 & 5 meters & US Geological Survey \\
\hline DOQQ & 1994 & 1994 & 1 meter & US Geological Survey \\
\hline DOQQ & 2001 & 2001 & 1 meter & US Geological Survey \\
\hline DOQQ & 2010 & 2010 & 0.5 meters & US Geological Survey \\
\hline
\end{tabular}

For each data year, both bank lines were digitized, and centerlines were created in a geographic information system (GIS) environment using midpoint distances between bank lines. Resulting centerlines were filtered to include segments bounded by successive points 300 feet (ft) distant from the stream centerline to provide a common scale for each data year. 


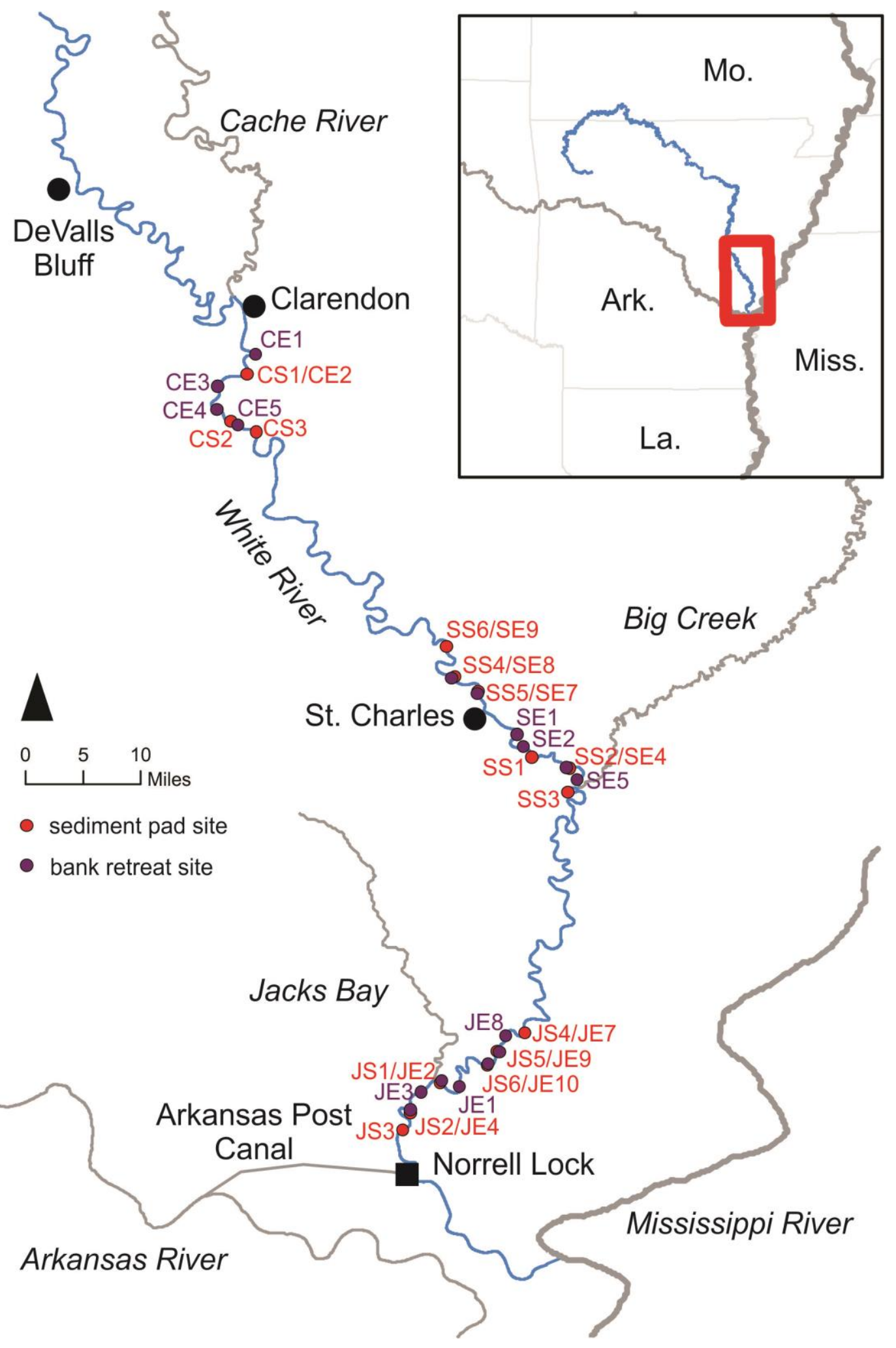

Figure 2.1 Location map of sediment pad and bank retreat measurement sites. Sites with both listed are collocated. 
Channel migration during the study period was estimated by superimposing the 1930 and 2010 channel centerlines and creating a series of polygons between successive points of intersection. Channel migration rate $(M)$ was estimated for each polygon as $M=A /(0.5 \times P) / y r$, where $A$ is the area of the polygon, $P$ is the perimeter of the polygon, and $y r$ the number of years between channel centerlines. Polygons with a total migration below $30 \mathrm{ft}$ for the entire study period were eliminated because of potential spatial registration error between datasets.

Bankfull width was estimated by measuring the distance between digitized bank lines every $1600 \mathrm{ft}$ along the river for each data year. Stream distance for width measurements was normalized to 2010 along-stream distance. Sinuosity was measured as the ratio of stream length to valley length.

Benchmarks were established between Clarendon and Norrell Lock to assess current rates and mechanisms of bank retreat (fig 2.1). The distance from the benchmark to the first vertical face of the bank was measured periodically to determine contemporary bank retreat rates (fig. 2.2).

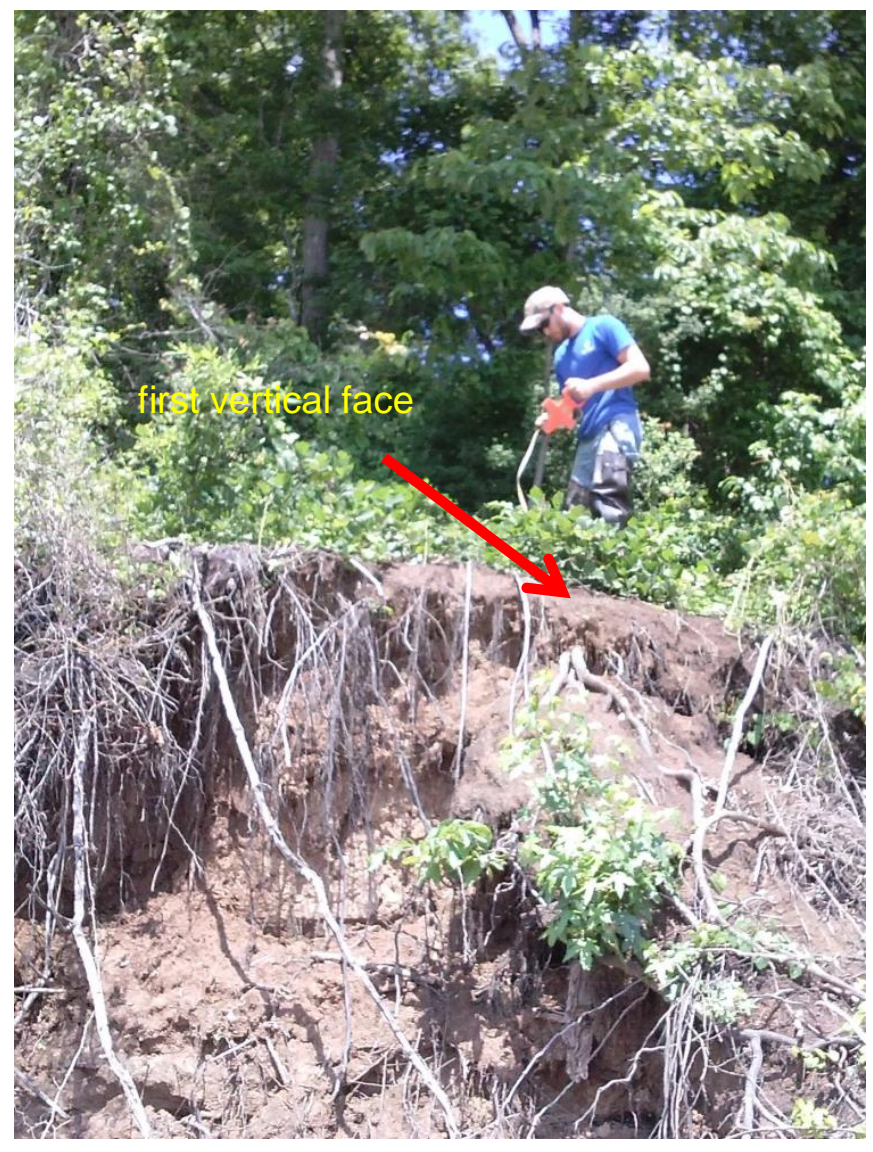

Figure 2.2. Photograph of field crew conducting bank retreat measurement. Distance was measured from benchmark to first vertical face of bank. (Photograph: Brandon Edwards, 2014) 


\subsubsection{Results}

Channel migration rates ranged from 0.43 feet per year (ft/yr) to $17.68 \mathrm{ft} / \mathrm{yr}$ between DeValls Bluff and Norrell Lock (fig. 2.3). The greatest migration rates were measured between DeValls Bluff and Clarendon, where it averaged $4.59 \mathrm{ft} / \mathrm{yr}$ and ranged from 0.59 to $17.68 \mathrm{ft} / \mathrm{yr}$. In comparison, channel position has remained relatively stable between Clarendon and St. Charles. Migration rates between Clarendon and St. Charles ranged from 0.49 and $4.27 \mathrm{ft} / \mathrm{yr}$ and averaged $2.13 \mathrm{ft} / \mathrm{yr}$. Below St. Charles, migration rates were only slightly higher, with an average of $2.30 \mathrm{ft} / \mathrm{yr}$, but were more variable, ranging from 0.43 to $9.51 \mathrm{ft} / \mathrm{yr}$.

Overall channel sinuosity remained stable over the entire study reach, increasing slightly from 1.81 to 1.85 between c. 1930-2010 (table 2.2). Channel sinuosity is highest between DeValls Bluff and Clarendon and decreased from 2.47 to 2.29 as stream length decreased, although there is variability throughout the study period. Punctuated decreases resulted from cutoff events. Sinuosity between Clarendon and St. Charles gradually increased from 1.73 to 1.80 . Sinuosity below St. Charles also gradually increased from 1.65 to 1.74 .

Channel width increased over most of the study reach throughout the study period (fig. 2.4). The average bankfull width between 1930 and 2010 ranged from 453 to $558 \mathrm{ft}$ (fig. 2.5). Approximately $1.31 \mathrm{ft} / \mathrm{yr}$ of bank widening occurred in the study reach, with the most rapid period of bank width increase between 1930 and 1950, and the majority of change took place over the upper 40 miles (mi) of the study reach. Since 1950, the majority of channel width increase occurred over the lower portion of the study area. The highest rates of change between river mi 25 and 80 occurred between 1984 and 1994 and between 1968 and 1984, over approximately the last 14 mi of the study reach (fig. 2.4).

Current bank retreat ranged from 0 to $25 \mathrm{ft}$ over the entire study reach (fig. 2.6), and rates ranged from 0 to $6.2 \mathrm{ft} / \mathrm{yr}$. Field observations suggest that the majority of bank retreat during the study period was the result of episodic mass wasting events, which likely explains variability in bank retreat amounts among sites. Bank retreat rates were fairly consistent across the study reach (fig. 2.4), and mean shortterm bank retreat rates were 2.56, 2.66, and $2.03 \mathrm{ft} / \mathrm{yr}$ for the Clarendon, St. Charles, and Jacks Bay areas, respectively. Mean bank retreat was $2.40 \mathrm{ft} / \mathrm{yr}$. These contemporary bank retreat rates are similar to the mean channel migration rate of $2.95 \mathrm{ft} / \mathrm{yr}$.

Table 2.2. Stream sinuosity by reach.

\begin{tabular}{lcccc}
\hline Year & $\begin{array}{c}\text { DeValls Bluff to } \\
\text { Clarendon }\end{array}$ & $\begin{array}{c}\text { Clarendon to St. } \\
\text { Charles }\end{array}$ & St. Charles to Norrell lock & Entire study reach \\
\hline 1930 & 2.47 & 1.73 & 1.65 & 1.81 \\
1950 & 2.51 & 1.75 & 1.69 & 1.81 \\
1968 & 2.28 & 1.77 & 1.69 & 1.81 \\
1984 & 2.33 & 1.78 & 1.70 & 1.83 \\
1994 & 2.36 & 1.79 & 1.72 & 1.85 \\
2001 & 2.38 & 1.79 & 1.72 & 1.86 \\
2010 & 2.29 & 1.80 & 1.74 & 1.85 \\
\hline
\end{tabular}




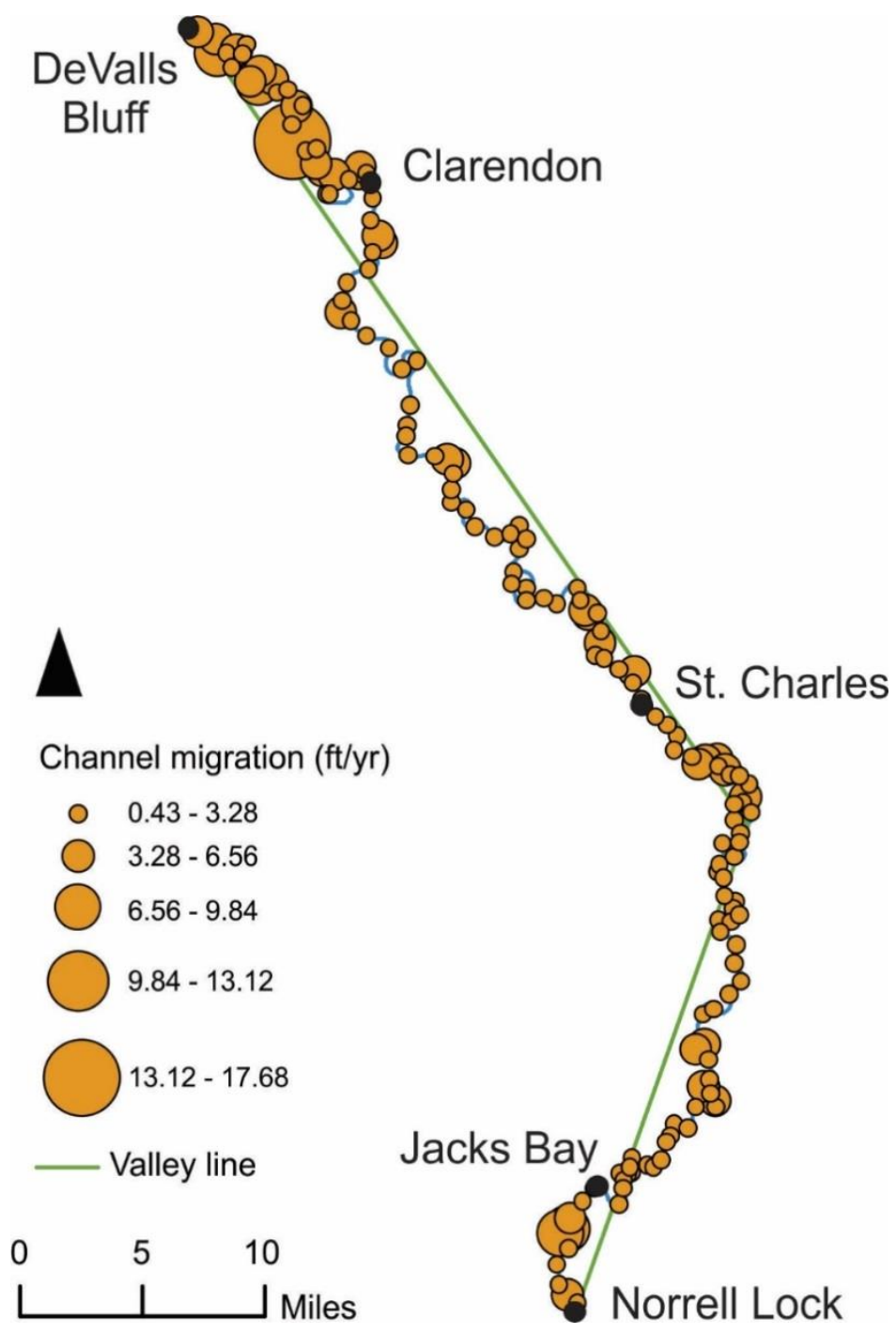

Figure 2.3 Channel migration rates, given in feet per year (ft/yr), between DeValls Bluff and the Norrell lock. Also shown is valley line used to to calculate stream sinuosity. 


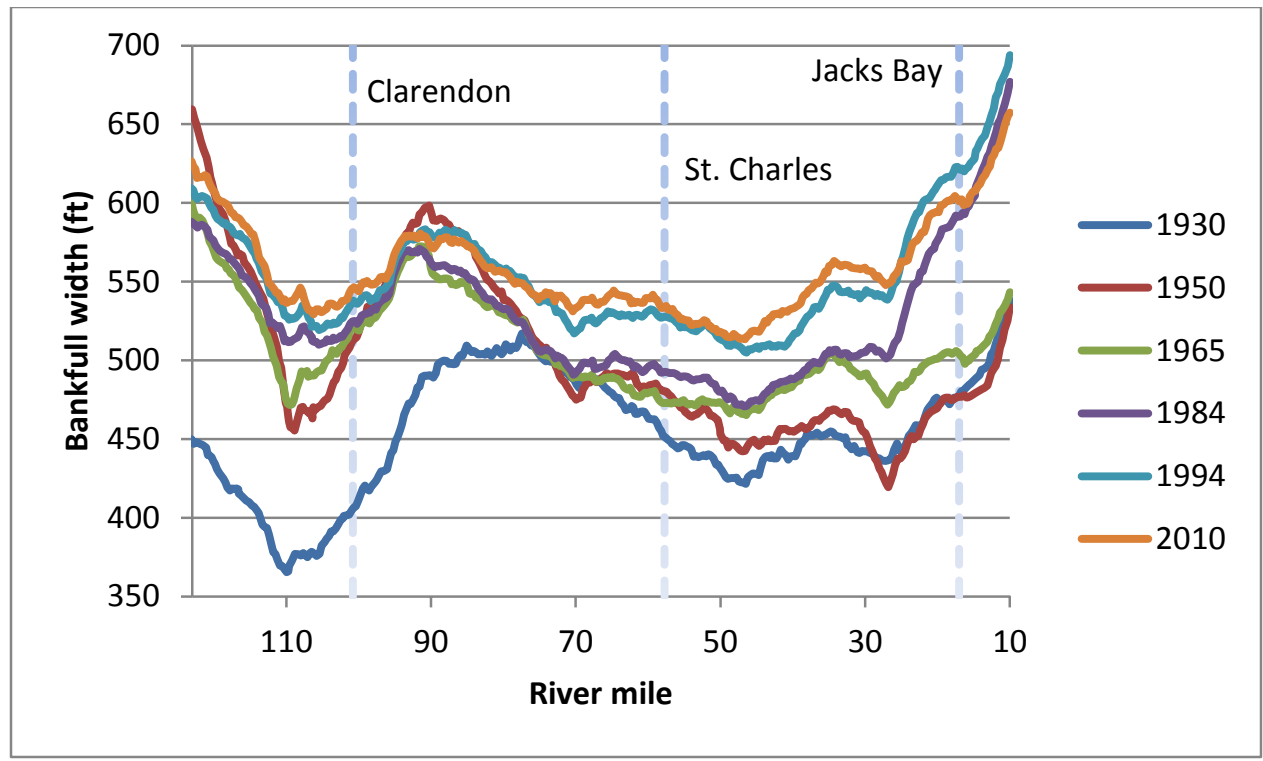

Figure 2.4 Bankfull width from 1930-2010. Shown are moving averages of bankfull width calculated from width measurments taken approximately every 1600 feet (ft) of stream distance.

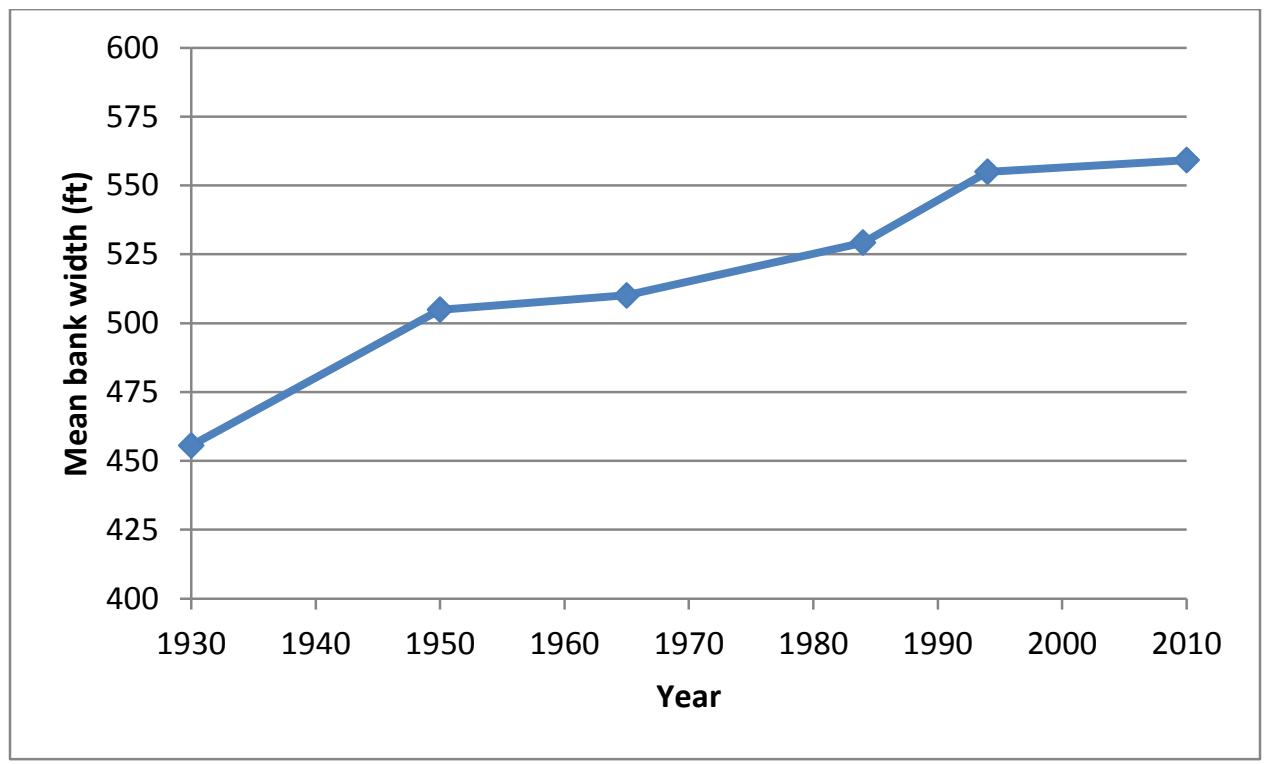

Figure 2.5 Mean bankfull width in feet (ft) for the entire study reach from 1930-2010. 

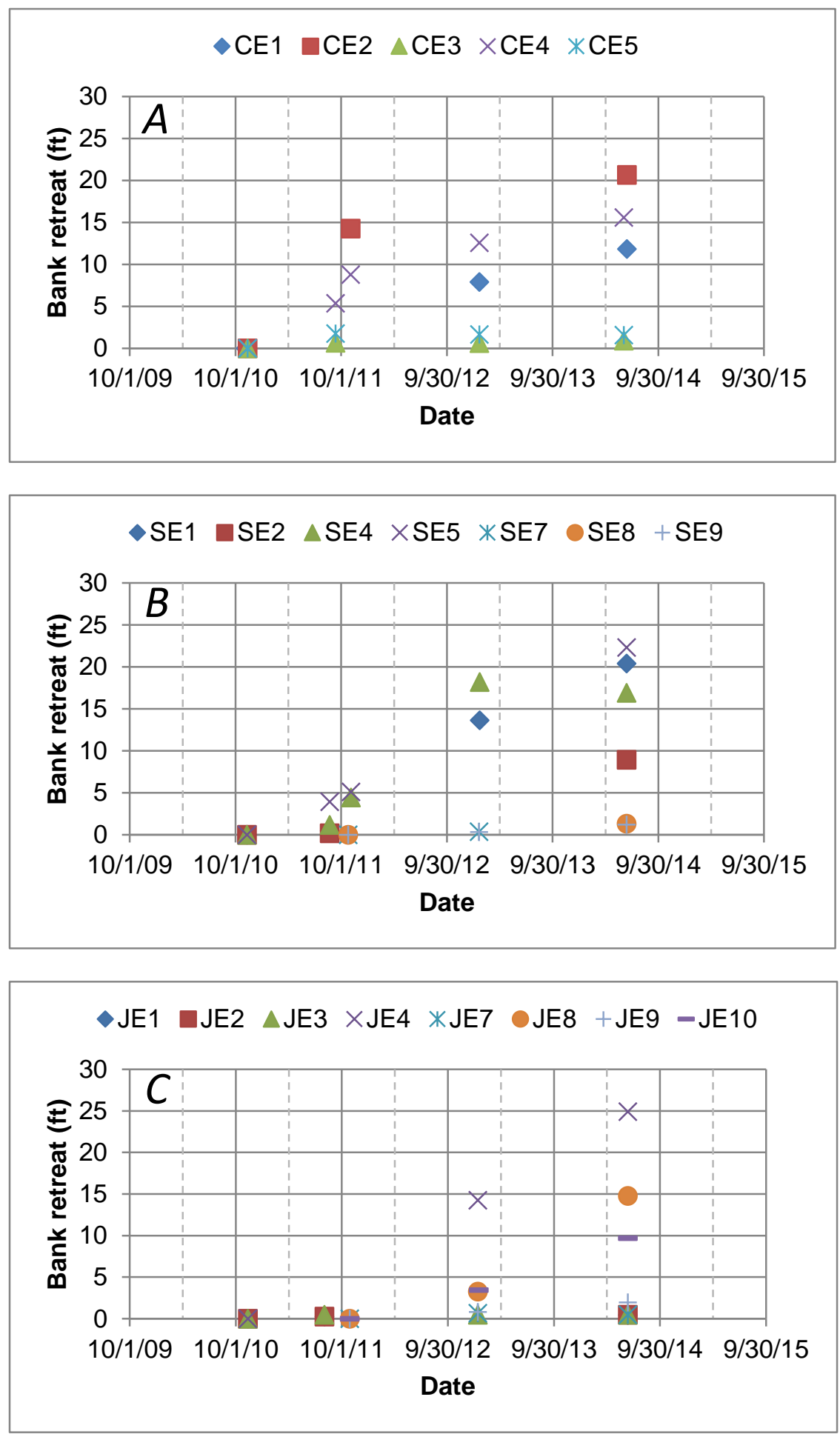

Figure 2.6 Amount of bank retreat (expressed in feet (ft)) for sites near A) Clarendon, (B) St. Charles, and (C) Jacks Bay (top, middle, and bottom panel, respectively). See figure 2.1 for site location reference. 


\subsection{Channel Incision}

\subsubsection{Methods}

A bank-height survey was conducted over a 3-day period from 21-23 August, 2014, to assess the degree and upstream limit of channel incision on the lower White River. A laser rangefinder was used to measure the vertical distance from the waterline to top of bank for each successive section of outer bank from the Norrell Lock to DeValls Bluff (fig. 2.1). Water surface elevation was stable during the survey period, but small changes did occur. Survey data were corrected for changes in water surface elevation over the 3-day period using stage collected at the Clarendon gaging station. Bed elevation data were taken from a 2013 hydrographic survey by the U.S. Army Corps of Engineers (USACE) Memphis District. Measurements were taken by a boat that was approximately $60 \mathrm{ft}$ from the bank. We conducted a field trial to estimate measurement error and found mean error was $\pm 0.6 \mathrm{ft}$ for bank height measurements.

\subsubsection{Results}

Bank-height survey data clearly showed incision over the lower half of the study reach (fig. 2.7), and incision is apparent in bed-elevation data (fig. 2.8). The incision knickpoint zone is estimated to be just upstream of St. Charles, approximately 48 mi upstream of Norrell Lock (river mi 10). Bank height above and below the estimated knickpoint area exhibits significantly different trends. The upward trend in bank height below the knickpoint identifies the slope of incision, $0.14 \mathrm{ft} / \mathrm{mi}$, in the incised reach. The upward trend in bank height appears to stop near the end of the study reach, but data are insufficient to draw a conclusion as to whether this is due to scatter, a local trend, or if it continues past the end of the study reach.

Above the knickpoint, the mean bank height above water surface was approximately $13.25 \mathrm{ft}$. A linear fit of bank height trend below the knickpoint predicts a bank height of $20.18 \mathrm{ft}$ at the end of the study reach. A moving average fit of bank height predicts a bank height of $18.86 \mathrm{ft}$ at the end of the study reach. These measurements yield an incision estimate of between 6.92 and $5.61 \mathrm{ft}$. If this rate of incision is extrapolated to the confluence of the White and Mississippi Rivers, $10 \mathrm{mi}$ from the lower boundary of the study reach, an additional $1.38 \mathrm{ft}$ of incision could be expected. However, the White River below the Arkansas Post Canal is part of the McClellan-Kerr navigation system and is maintained at greater depth through dredging, so that extrapolation is not robust. 


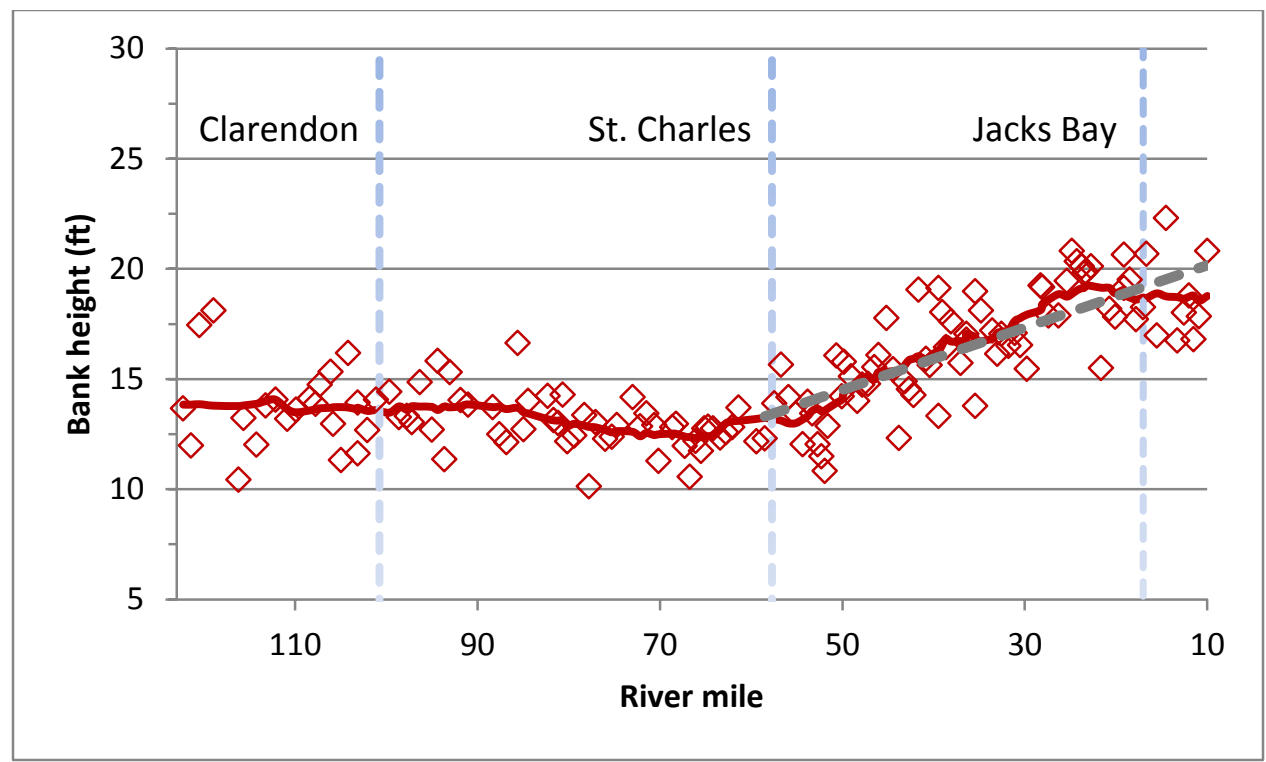

Figure 2.7 Bank height (expressed in feet (ft)) above water surface on the lower White River on 21-23 August, 2014. The solid red curve is a moving average trend of bank height measurements. The dashed gray line represents the linear trend in bank height below the knickpoint zone.

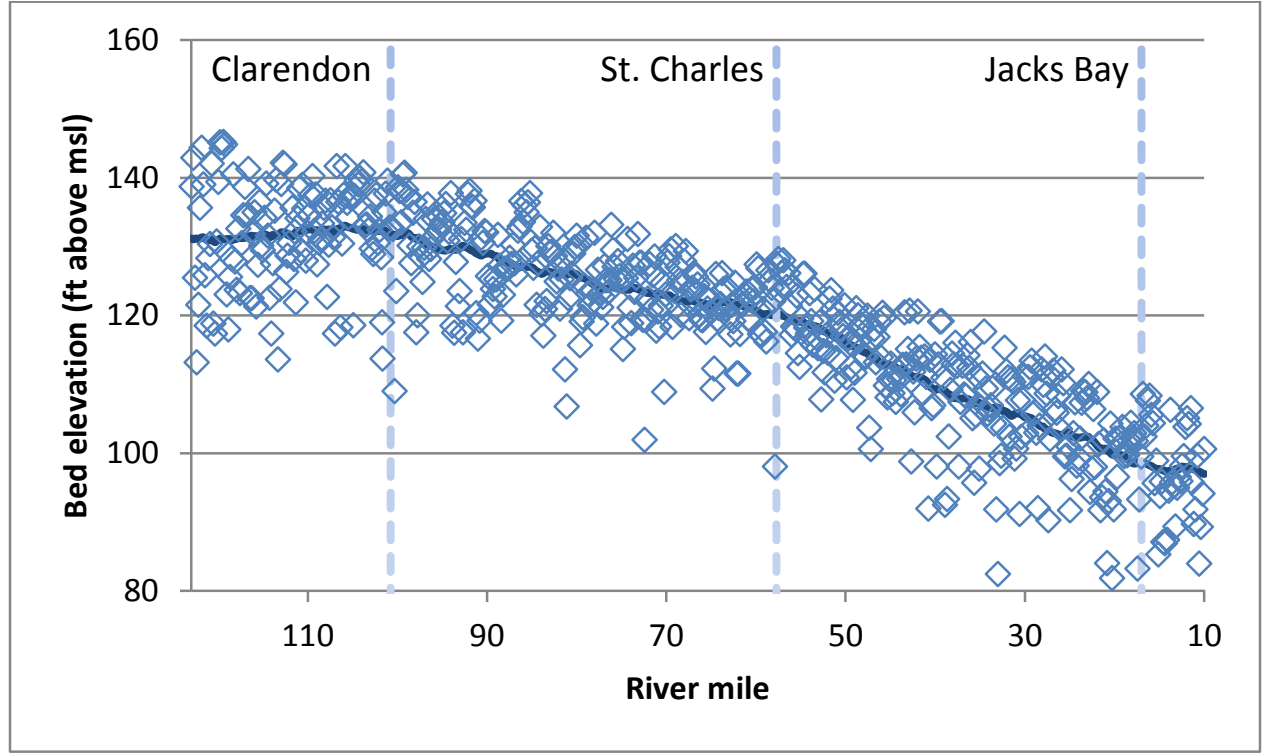

Figure 2.8 Bed elevation (expressed in feet ( $\mathrm{ft}$ ) above mean sea level $(\mathrm{ms} /)$ ) from 2013 thalweg survey. Solid blue line is the moving average of the thalweg values. A break in slope is apparent near St. Charles. 


\subsection{Sedimentation Rates}

\subsubsection{Methods}

Contemporary sedimentation rates were measured by placing a 2-3 square foot sediment pad (1-2 in. thick) made of feldspar clay at the soil surface. Feldspar powder forms a distinct horizon when exposed to the elements and marks the location of the surface at the time of installation. Deposition was estimated at each pad by periodically measuring the amount of deposition that occurred above the sediment pad.

Feldspar sediment pad transects were established in 2010 and 2011 between Clarendon and Norrell Lock at the Arkansas Post Canal (fig. 2.1). A total of three transects were established south of Clarendon, and six transects were established (three north and three south) around St. Charles and Jacks Bay. Transects started at the bank and extended approximately 2,950 ft into the floodplain except where distance was limited by water features. Spacing was approximately $330 \mathrm{ft}$ between pads. During the study, deposition was measured after annual overbank to assess sedimentation rates.

\subsubsection{Results}

Deposition was highest at the bank and decreased landward from the bank, although some control on deposition is exhibited by local topography (fig. 2.9). These deposition patterns along transects were consistent over the entire study reach. Total measured top-bank deposition among transects was highly variable, ranging from negligible to approximately 4.8 in over 4 years. Top-bank deposition rates ranged from 0 to approximately 1.35 in./yr (fig. 2.9).

Overall deposition rates increased slightly downstream (fig. 2.9). Mean deposition rates for all sediment pads in each group of transects were $0.20,0.24$, and $0.28 \mathrm{in} . / \mathrm{yr}$ for the Clarendon, St. Charles, and Jacks Bay sites, respectively. However, variability in deposition rates among transects from each group increased downstream. For example, the greatest recorded deposition rates were in the Jacks Bay area, but three of the six Jacks Bay transects experienced low or negligible deposition (fig. 2.9). Measured rates in the Clarendon and St. Charles areas were more consistent among individual transects. 

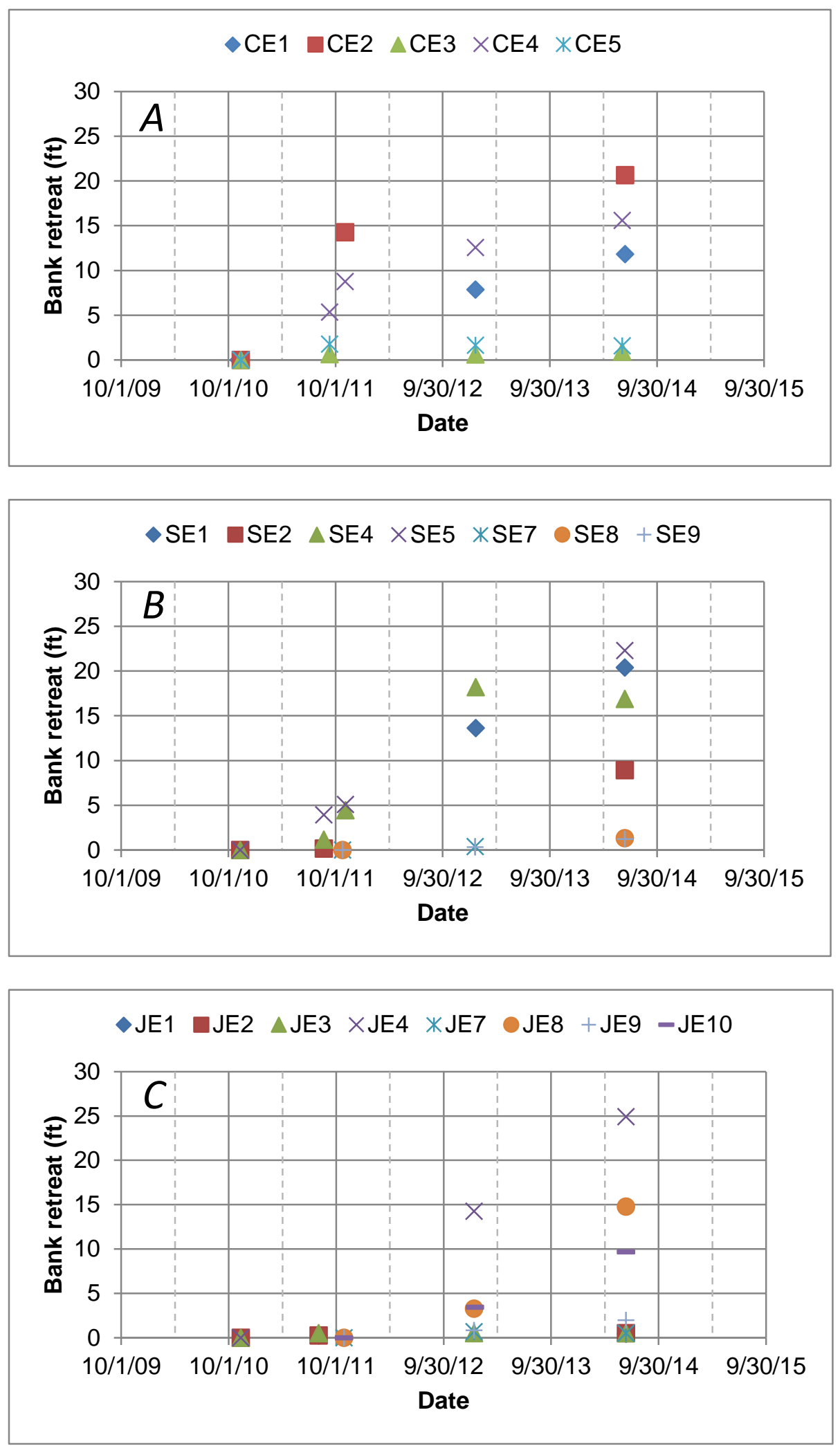

Figure 2.9 Sediment deposition rates for the $(A)$ Clarendon area, $(B)$ St. Charles area, and (C) Jacks Bay area sites, respectively. Measurements are in feet (ft) and inches per year (in./yr). 


\subsection{Interpretation of Geomorphic Analyses}

Results of the bank-height survey and historical analyses indicate that the study area can be divided into three distinct reaches based on channel bed slope, channel migration rates, sinuosity, and trends in channel adjustment. The section between DeValls Bluff and Clarendon is characterized by high sinuosity and high migration rates and low bed slope. Between 1930 and 2010, this reach experienced decreasing sinuosity due to cutoff events that shortened stream length.

The reach between Clarendon and St. Charles is characterized by a higher bed slope and a relatively stable channel with low channel migration rates and low sinuosity. The reach between St. Charles and Norrell Lock is incised. This reach also has higher migration rates, higher bed slope, and higher sinuosity than between Clarendon and St. Charles. Sinuosity in both increased slightly over the study period, indicating an increase in stream length.

Rapid channel width increase between 1930 and 1950 in the upper portion of the study area, followed by a more gradual, consistent increase in bankfull width, indicates a rapid response to dam construction, similar to that found in studies documenting temporal sequencing of geomorphic response to dam closure (as with Grams and others, 2007). Bull Shoals dam was not completed until 1951, but dams on major tributaries - the Norfork and Black Rivers - were completed in 1943 and 1948. Reduction in sediment load coupled with flow regulation, specifically an increase in low-flow discharge starting during the early to mid-1940s (Craig and others, 2001), is probably responsible for the increase in average bankfull width during this period. Bankfull width over the lower half of the study reach changed little between 1930-1950, suggesting the influence of the dam closure diminished downstream.

The dominant channel adjustment in the lower portion of the study area was channel incision followed by bank widening. Results of the bank-height survey clearly show an incised reach from between St. Charles and the end of the study area, with an incision of $6.5 \mathrm{ft}$ at Norrell Lock. Significant bank widening occurred between 1965 and 1984 over approximately the lowest $15 \mathrm{mi}$ of the study reach, followed by significant bank widening between river mi 25 and river mi 80 from 1984 to 1994.

Lack of historical bathymetric data makes it difficult to estimate the temporal connection between incision and bank widening on the lower White River, but results indicate that incision preceded lateral erosion, which implies that the bed was more erodible until a threshold was reached after 1965, likely due to the stabilizing presence provided by forested banks. Most likely, incision led to an over-steepening of the banks, increases in bank height, and bank toe removal (for example, Simon and Hupp, 1992), which decreased bank stability. Relatively little bank widening after 1984 in the lowest 15 mi of the study reach suggests that the system may be trending toward a new equilibrium following upstream advancement of the knickpoint.

Bank widening after 1984 was substantial over the middle portion of the study area, suggesting upstream migration of incision followed by bank widening in a similar fashion as above, which is consistent with field observations of headcutting on small tributaries in the area upstream of Jacks Bay during the 1990s (Dennis Sharp, retired U.S. Fish and Wildlife Service, personal commun.). Bank widening decreased upstream, which implies an upstream distance decay of response to a lowered base level, similar to that noted by other researchers (such as Musselman, 2011). The similarity in bank width between 1994 and 2010 suggests the lower White River may have entered a period of equilibrium relative to the changes that accompanied the anthropogenic modifications of the early 20th century.

The reach between DeValls Bluff and Clarendon appears to have a fundamentally different morphology than below Clarendon. Low slope (fig. 2.8) and punctuated decreases in sinuosity via cutoff events (table 2.2) suggest aggradational conditions and mechanisms to increase slope, in contrast to the two other reaches. Sinuosity above Clarendon is approximately double the sinuosity below, even for the first measurement period. The break in the slope of bed elevation and the difference in sinuosity suggests 
a local base level (Leopold and Bull, 1979) may exist for the river above that point. In a specific gage analysis, Shaffner (2012) observed significant degradation at DeValls Bluff compared with Clarendon following dam closure, suggesting little or no substantive change occurred in the channel at Clarendon. There are several possible explanations for this, including an inerodible bed at Clarendon, effects of faulting (Schumm and Spitz, 1996), and the influence of the Cache River from its confluence just upstream of Clarendon. It is possible that increased sediment load from bank widening following dam closure exacerbated a pre-existing aggradational condition.

The combined geomorphic response of the White River to flow regulation and the lowered base level suggests a transition between the dominance of headwater-downstream influences and upstream effects from the Mississippi exists between Clarendon and St. Charles. Little changed in bankfull width between 1930-1950 over the lower half of the study reach, suggesting that either the effects of dam closure diminished downstream or were overwhelmed by backwater effects. Conversely, bank width in the uppermost portion of the study area has been relatively stable when compared with the downstream since 1950, suggesting the upstream effects have little influence on the lowered base level.

Incision below St. Charles may affect sedimentation patterns in the incised reach. Sediment deposition variability increases in the downstream direction, particularly in the incised reach (fig. 2.10). As mean bank height increases through the incised reach and the connectivity of river flow to the floodplain likely decreases (as is expected to happen with decreased peak flows as well), deposition is likely focused on areas of locally low bank height. Areas with high bank heights in the incised reach are likely bereft of deposition, except under extreme conditions, whereas deposition is fairly consistent with bank height in the unincised reach (fig. 2.10). 

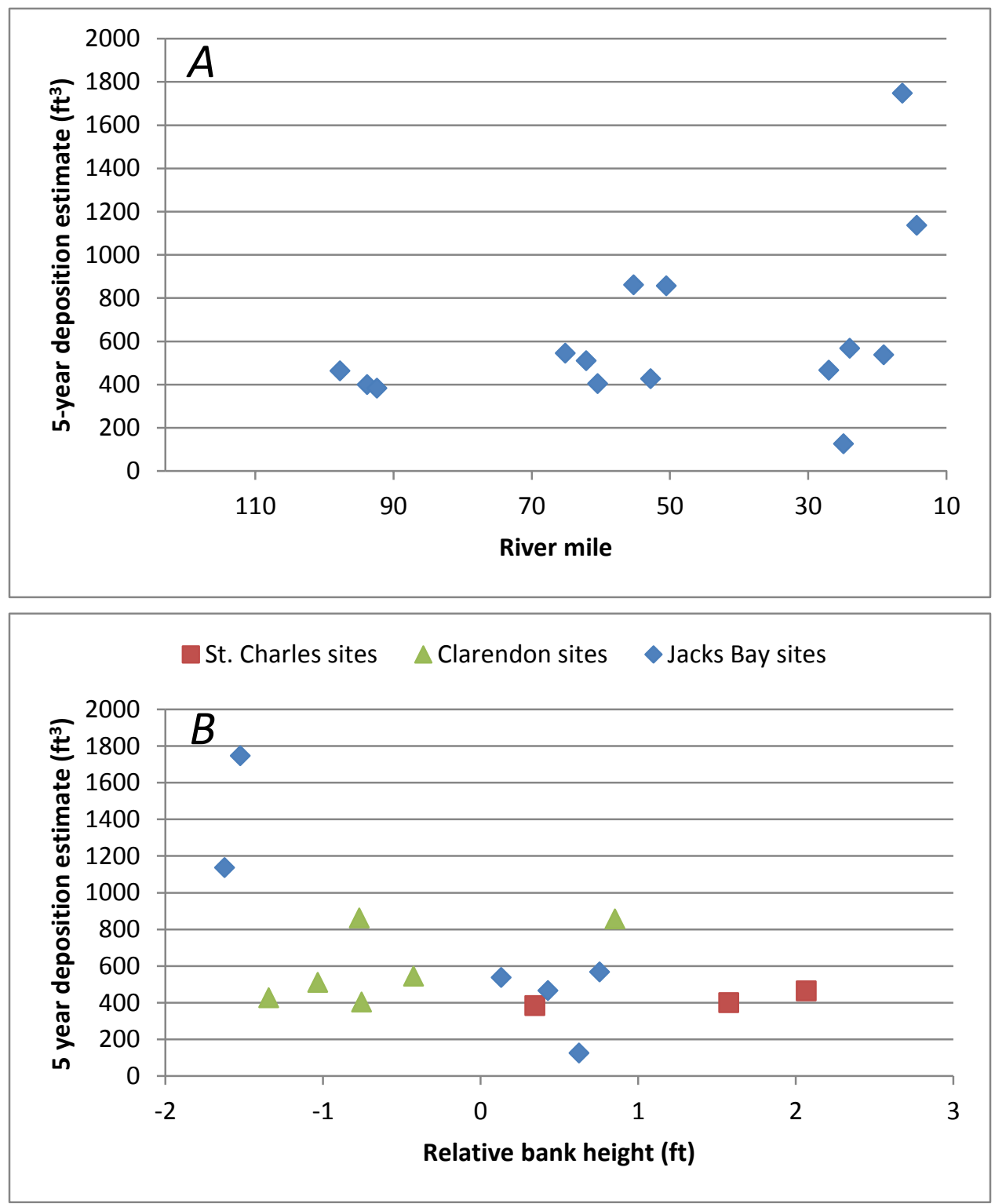

Figure 2.10 Deposition rates (in cubic feet $\left(\mathrm{ft}^{3}\right)$ ) integrated over first 500 miles of transects extrapolated to 5 -year total deposition versus $(A)$ along-stream distance and $(B)$ local bank height (expressed in feet $(\mathrm{ft})$ ) relative to mean trend in bank height. 


\section{Accuracy of the HEC-GeoRAS Model in Predicting Water Depths in the Floodplain}

\subsection{Methods}

The HEC-RAS (Hydrologic Engineering Centers River Analysis System) parameterized model for the White River by Lin (Final Report: White River Basin Comprehensive Study: Development of Unsteady-State Model, undated, unpublished report to the U.S. Army Corps of Engineers Memphis District) consisted of channel cross-sections from a 2009 hydrographic survey performed by the USACE. The floodplain digital elevation model (DEM) was a composite of the USGS $10 \mathrm{~m}(\sim 32.8 \mathrm{ft})$ DEM and the Arkansas State $5 \mathrm{~m}$ ( 16.4 ft) DEM. Manning's $n$ roughness coefficients for the floodplain and channel were chosen to maximize agreement between observed and modeled channel flows from 1965 to 2009. The model boundary includes the lower White River floodplain with a buffer of terraces or levees that do not flood (fig. 3.1).

Upper and lower boundary conditions are required parameters that specify the starting and ending water surface elevation. We used the daily stage from the White River gauge at Clarendon, Ark., (USACE WR116) for the upstream boundary and interpolated daily stage for the downstream boundary at the confluence of the White River and Mississippi River (fig. 3.1). We installed 28 water-level monitoring stations in three reaches (fig. 3.1) and distributed them among the three Potential Natural Vegetation (PNV) classes that occupied the majority of the floodplain. Water monitoring stations were also designed to measure shallow water table depths, so they were constructed as vented wells using 3-ft long, slotted PVC pipe and installed to at least $1.5 \mathrm{ft}$ below the ground's surface. At each station, water depth was monitored using pressure transducers, and the data range is from September 2011 to December 2014. The recorded water level data created a history of observed flooding depths for each station for comparison to modeled depths.

\subsection{Results}

The model's accuracy varied in its ability to model flood depths by reach. The range of error for all monitoring sites in modeled flooding depths was $\pm 8 \mathrm{ft}$. Removing the outlier sites - CC2 and J12reduced the range of error to $\pm 5 \mathrm{ft}$. The average root mean square error (RMSE) was $3.64 \mathrm{ft}$ with a range of $11.18 \mathrm{ft}$. The model replicated flood depths in the St. Charles reach (with outlier CC2 excluded) and showed the least difference when compared with observed flood depth. Replicated flood depths in the Jacks Bay reach showed the greatest difference when compared with observed flood depth (fig. 3.2). Differences between the actual and modeled flood depths in the Clarendon reach were intermediate to the Jacks Bay reach and the St. Charles reach (fig. 3.2). Despite the range of errors in modeled flood depths, the parameterization of HEC-RAS was successful in replicating observed water surface slopes as indicated by the 1:1 line. However, the model estimated more gradual slopes than the 1:1 line for most monitoring stations in the St. Charles reach, so the model is less useful in that instance. 


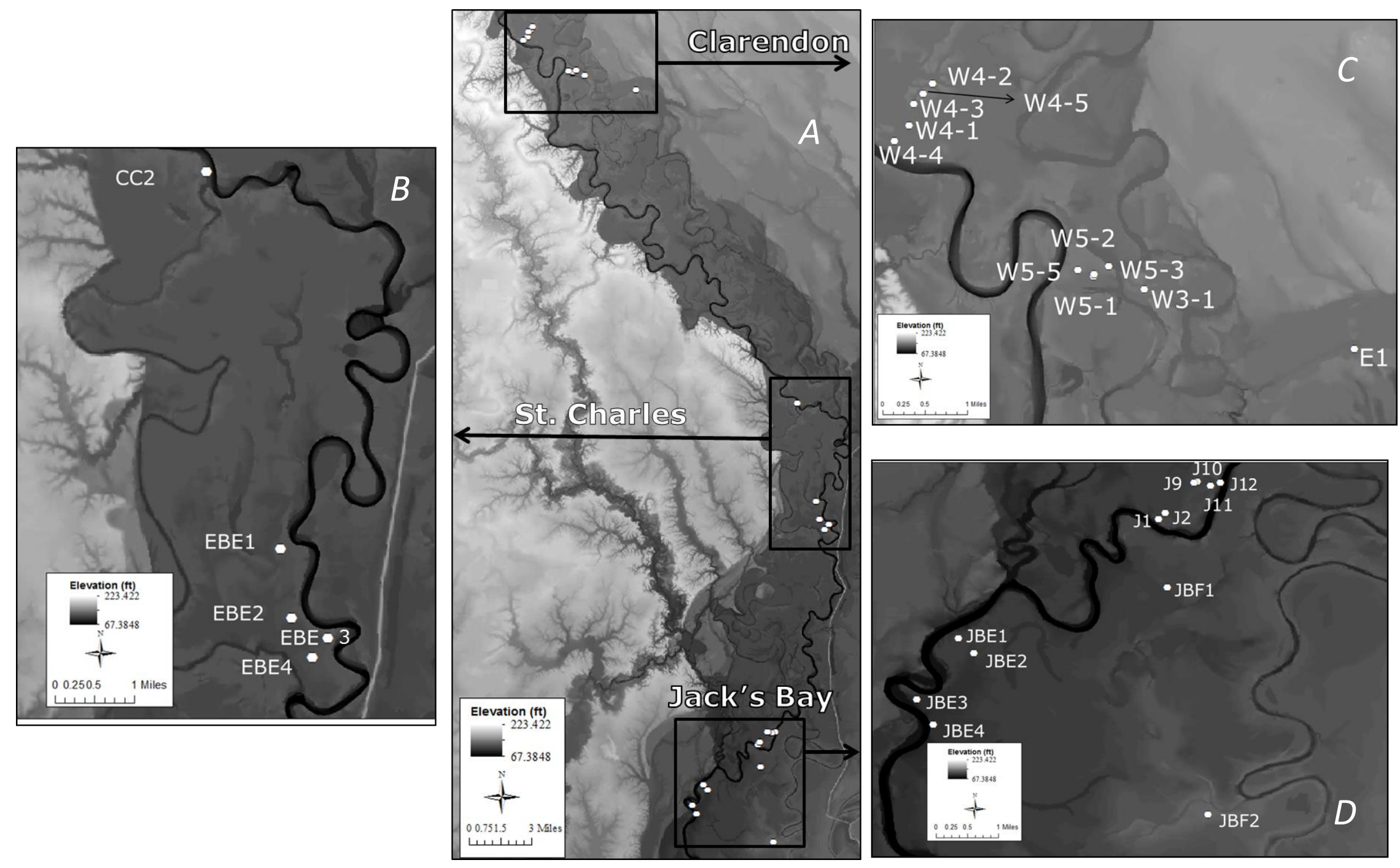

Figure 3.1 Distribution of water monitoring stations by reach: $(A)$ overall distribution; $(B)$ Clarendon area; $(C)$ St. Charles area; and $(D)$ Jacks Bay area. Source: 10 m USGS digital elevation map (http://nationalmap.gov/elevation.html). 


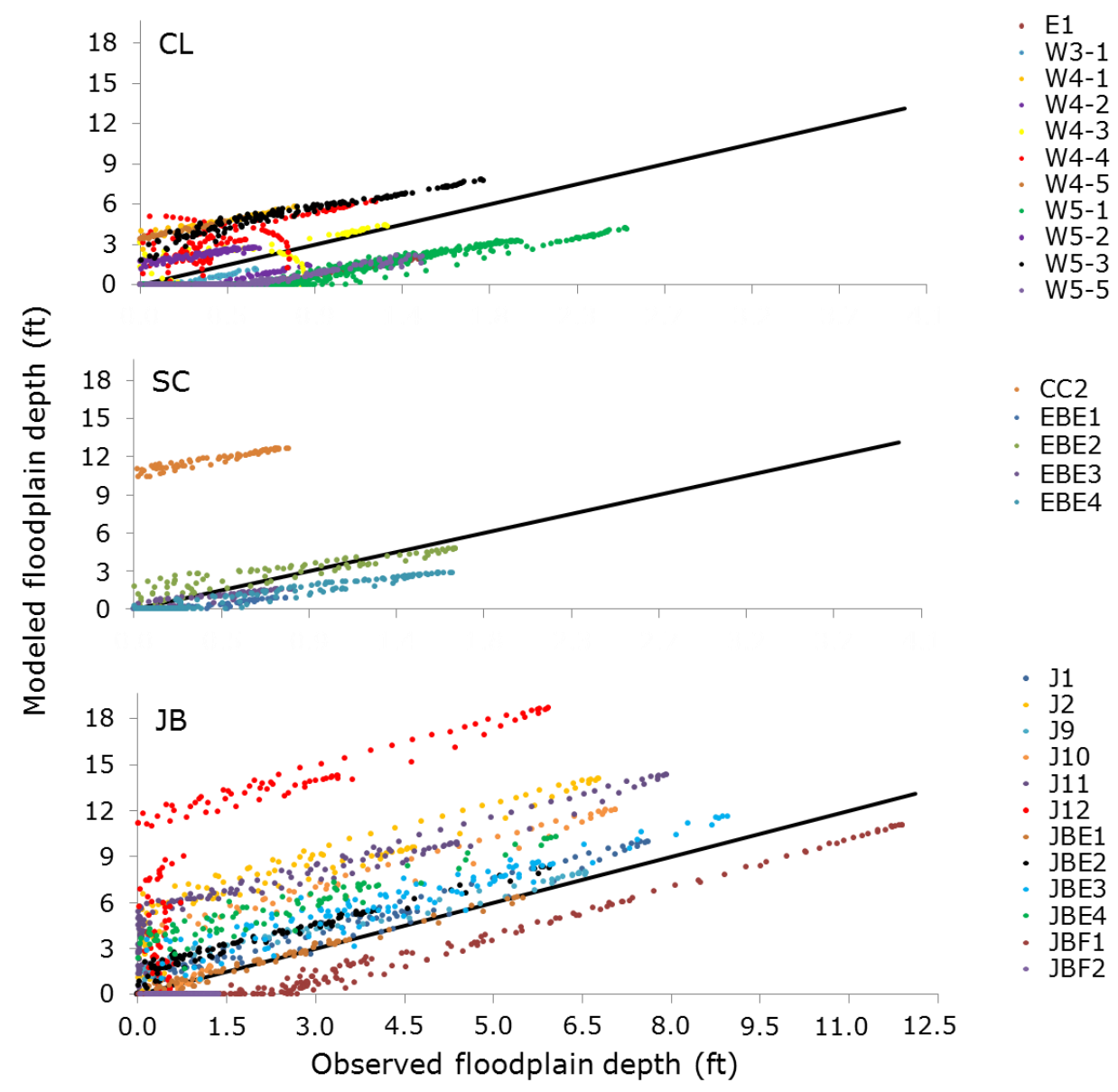

Figure 3.2 Observed floodplain depths (in feet (ft)) compared to modeled floodplain depths at 28 well monitoring stations by reach: Clarendon (CL), St. Charles (SC), Jacks Bay (JB). Model matches observed if the slope is along the 1:1 line (solid black line).

\subsection{Discussion}

The parameterized HEC-RAS model performance was not ideal for estimating the impact on vegetation communities; however, understanding the limitations of the model can help improve the parameterization for better floodplain modeling. Small variations in flooding, on the scale of inches, influence the flooding regime of vegetation communities (Pollock and others, 1998), and the model was not precise enough for site-specific assessment. While the model and field data corresponded on incremental variations in flood depth (1:1), a non-zero intercept in the relationship (fig. 3.3) indicates the source of errors is more likely a low-resolution DEM (Casas, 2006) than the model. Also, the coarseness of the DEM does not align with current bank positions. Monitoring stations close to the river like J12 and $\mathrm{CC} 2$ had the highest error in flooding depth (fig. 3.2). Improvements in the parameterization of the model, like using lidar for more accurate and precise floodplain elevations or using next-generation hydraulic models, would be helpful in understanding floodplain flows. 


\section{Stand Establishment Patterns of Bottomland Hardwoods Within Selected Plant Communities}

Before completion of the geomorphic analysis of the river reaches, we established proportional vegetation plots within the three PNV classes of the lower White River floodplain, as originally classified by Klimas and others (2009) and later modified by Heitmeyer and Foti (2014). These classes were Riverine Backwater-Lower Zone, Riverine Overbank-Natural Levee, and Hardwood Flat. The combined area of these three classes represents over 80 percent of the total acreage within the study area. In addition to being the three most common PNV classes within the study area, these classes represent three of the most common geomorphic settings and tree community types discussed in bottomland hardwood literature: backswamp, levee, and precipitation-driven oak flats.

The Riverine Backwater-Lower Zone PNV class is the part of the floodplain that is generally lowest in elevation and receives overbank flooding from the river more often than every other year. This part is sometimes referred to as backswamp but can comprise a significant acreage of ridge and swale habitat. The tree species described as dominant within The Riverine Backwater-Lower Zone PNV class by Klimas and others (2009) include overcup oak (Quercus lyrata) with Nuttall oak (Q. texana) or pin oak (Q. palustris) as associates and baldcypress (Taxodium distichum) and water tupelo (Nyssa aquatica) in swales and along internal drainages.

The Riverine Overbank-Natural Levee PNV class is the part of the floodplain that is relatively high in elevation, adjacent to the active river channel, and receives overbank flooding from the river more often than every 5 years. However, the relative elevation of this natural levee habitat type is often highly variable due to historical fluvial activity; therefore, the hydrologic and accompanying vegetation community types may also vary greatly within this PNV class. Trees described by Klimas and others (2009) as dominant within the Riverine Overbank-Natural Levee PNV class include sycamore (Platanus occidentalis), eastern cottonwood (Populus deltoides), and black willow (Salix nigra) on the riverfront, and pecan (Carya illinoensis), cedar elm (Ulmus crassifolia), box elder (Acer negundo), sugarberry (Celtis laevigata), Nuttall oak, and willow and water oak (Q. nigra) off channel.

The Hardwood Flat PNV class is the part of the floodplain outside the 5-year flood zone that has a hydrologic regime closely tied to precipitation. These are high elevation oak stands scattered sparsely throughout both the Riverine Backwater-Lower Zone and Riverine Overbank-Natural Levee PNV classes; most are Holocene point bar and backswamp deposits. Trees described by Klimas and others (2009) as dominant within the Hardwood Flat PNV class include delta post oak (Quercus similis), water oak, swamp chestnut oak (Q. michauxii), and mockernut hickory (C. alba), with willow oak, Nuttall oak, and green ash in vernal pools.

\subsection{Methods}

\subsubsection{Vegetation Plots}

Each PNV class was sampled proportional to its relative percent cover (table 4.1). To capture the full range of hydrologic conditions found throughout the White River floodplain, plots were further stratified by river reach (Clarendon, Saint Charles, and Jacks Bay) and distance to the river channel (near vs. far). Plots near Clarendon are near the northern extent of the study area, approximately 90 river mi from the confluence of the White and Mississippi rivers. This part of the White River floodplain receives little backwater effect from the Mississippi River. Plots near St. Charles are approximately 50 river mi from the mouth of the White River and these plots receive semi-annual backwater flooding from the Mississippi River. The plots near Jacks Bay are approximately 15 river mi from the confluence of the 
White and Mississippi Rivers and receive annual backwater flooding from the Mississippi River. Plots were evenly distributed close to and distant from the river channel.

In the summer of 2011 and 2012 (summer 2014 for tree ring plots), standard biometric techniques were used to assess stem density, basal area, and tree species importance values at each of the 81 vegetation sampling plots. At each of the 81 sites, a 0.1 acre (ac) (0.04 hectare (ha)) plot was established using the Forest Inventory and Analysis (FIA) plot design (U.S. Forest Service, 2011). At each vegetation sampling plot, the diameter at breast height ( $\mathrm{dbh})$ of each tree ( $\mathrm{dbh}>3 \mathrm{in}$.) was recorded, and each tree was identified to species. From these data, stem densities and basal areas for each tree species were calculated. Because geomorphic findings indicated differences among reaches, plots were reclassified based on reach, and all analyses was conducted based on reach. Species composition, basal area, stem density, and diameter distributions of major species within each reach were summarized for comparative purposes.

\subsubsection{Stand Development-Tree Ring Analysis}

So stand development could be evaluated, a minimum of four plots were established within each reach of the river (Clarendon, St. Charles, and Jacks Bay) and located in areas representative of locally dominant PNV classes. In Clarendon, four plots were established in 2014 and two in 2015; in St. Charles, four plots were established in 2015; and in Jacks Bay, five plots were established in 2014 and two plots in 2015. Therefore, the number of plots for each reach were six in Clarendon, four in St. Charles, and seven in Jacks Bay. Abnormally high flood conditions during the 2015 growing season precluded establishment of additional plots. The center of each plot was randomly selected and the plot diameter extended to include the 20 nearest, living trees with $\mathrm{dbh} \geq 3.1 \mathrm{in}$. We collected two increment cores from each of the 20 trees at a height of 1.6-3.3 ft depending on basal flaring or evidence of rot.

In total, we cored 340 trees. Cores were returned to the laboratory where they were oven dried at $104^{\circ} \mathrm{F}$ for a minimum of 48 hours. Cores were then mounted and sanded with progressively finer grit sandpaper until individual tree rings were clearly visible under a microscope (Stokes and Smiley, 1996; Orvis and Grissino-Mayer, 2002). Trees were aged by counting annual rings, and cross-dating among trees was aided by identifying signature calendar years (Yamaguchi, 1991). For age structure, we estimated the date of the first year of growth (pith) for increment cores that did not contain the pith ring using a concentric circle pith estimator (Applequist, 1958). The error associated with the age-to-core height was assumed to be within the resolution of the age-class bins (10 years) and was not estimated (Margolis and Balmat, 2009).

\subsection{Results}

\subsubsection{Stand Diameter Distribution}

A total of 103 vegetation plots were sampled: 36 plots (3.5-ac sampling area) in the Clarendon reach, 18 plots (1.8-ac sampling area) in the St. Charles reach, and 49 plots (4.8-ac sampling area) in the Jacks Bay reach. Total basal area and stem density by reach varied from 138.8 square feet per acre $\left(\mathrm{ft}^{2} / \mathrm{ac}\right)$ to $121.9 \mathrm{ft}^{2} / \mathrm{ac}$ in the south reach. Stem densities varied from 229.5 stems per acre (stems/ac) in the Clarendon reach to 163.9 stems/ac in the St. Charles reach.

At a species level, regardless of reach, overcup oak and sugarberry had the greatest basal areas (table 4.1). In the Clarendon reach, overcup oak $\left(23.0 \mathrm{ft}^{2} / \mathrm{ac}\right)$ and sugarberry $\left(22.9 \mathrm{ft}^{2} / \mathrm{ac}\right)$ had nearly identical basal areas, although sugarberry had 50.8 stems/ac; overcup oak only had 16.4 stems/ac. In the St. Charles reach, overcup oak had a greater basal area $\left(24.8 \mathrm{ft}^{2} / \mathrm{ac}\right)$ and lower stem density 
(18.5 stems/ac) than did sugarberry (basal area $18.2 \mathrm{ft}^{2} / \mathrm{ac}$; stem density 42.3 stems/ac). In the Jacks Bay reach, basal area was more skewed to overcup oak $\left(36.7 \mathrm{ft}^{2} / \mathrm{ac}\right)$ compared to sugarberry $\left(23.1 \mathrm{ft}^{2} / \mathrm{ac}\right)$, but sugarberry still had higher stem densities (55.5 stems/ac) than overcup (38.2 stems/ac).

Table 4.1. Total basal area (BA) and stems per acre of most common species within three designated reaches of the White River floodplain. Tree species are as follows: FRPE= Fraxinus pennsylvanica; ULAM = UImus americana; QUTE = Quercus texana; CELA = Celtis laevigata; and QULY = $\mathrm{Q}$. lyrata.

\begin{tabular}{llrrrrrc}
\hline & & FRPE & ULAM & QUTE & CELA & QULY & Total \\
\hline Clarendon area & BA (ft ${ }^{2} /$ acre $)$ & 14.211 & 6.488 & 9.114 & 22.923 & 22.954 & 121.900 \\
& Stems/acre & 12.916 & 18.656 & 5.166 & 50.801 & 16.360 & 229.461 \\
St. Charles area & BA (ft ${ }^{2} /$ acre $)$ & 13.908 & 13.143 & 6.834 & 18.224 & 24.883 & 138.755 \\
& Stems/acre & 8.140 & 46.669 & 5.969 & 42.328 & 18.450 & 163.883 \\
& & & & & & & \\
Jacks Bay area & BA $\left(\mathrm{ft}^{2} / \mathrm{acre}\right)$ & 9.307 & 2.353 & 14.703 & 23.105 & 36.667 & 121.999 \\
& Stems/acre & 14.811 & 10.847 & 8.344 & 55.488 & 38.174 & 216.694 \\
\hline
\end{tabular}

Diameter distribution charts (fig. 4.1) should be interpreted with caution because size does not necessarily indicate age; however, if we assume that smaller size classes are younger stems, then the diameter distributions suggest that overcup oak recently regenerated based on the number of stems in the lower two size classes. The Jacks Bay reach, however, supported far more overcup oak stems in the smaller size classes than any other reach. In the Clarendon and St. Charles reaches, sugarberry and American elm had the largest number of stems in the smallest size classes, but in the Jacks Bay reach, sugarberry, water hickory, and overcup oak all had high stem numbers in the small size classes. In those reaches, overcup oak regeneration was not as prevalent.

\subsubsection{Stand Development}

Tree ring analyses indicated that in general sugarberry and American elm were younger than overcup oak and the majority of regeneration occurred following the 1940s (fig. 4.2). Even so, overcup oak regenerated continuously on the Jacks Bay reach, with about 46 stems/ac established between 1925 and 1955. The tree ring analyses show that overcup oak is not regenerating in the St. Charles and Clarendon reaches, but this may be an artifact of sampling, as few overcup oak trees were cored in these sections. Diameter distribution data indicated that there were $<8$ stems/ac in the smallest size classes on both reaches. Although most sugarberry stems established since 1940, there were six sugarberry trees that established before 1900 with the oldest stem established in 1830 .

\subsection{Discussion}

Basal area and diameter distributions of the species are not surprising. The shade-tolerant sugarberry, and to some extent American elm, often have high basal areas in bottomland hardwood forests supported by a large number of trees in the smaller size classes. In contrast, overcup oak tended to have fewer stems in the smaller size classes than sugarberry, but overcup oak had a greater number of stems in the larger size classes. Overcup oak did appear to regenerate successfully in all reaches in the recent past, but the Jack's Bay reach supported the most stems in the smaller size classes. Stem densities and basal area on all reaches are greater than recommended for priority wildlife in the region (Lower Mississippi Valley Joint Venture Forest Resource Conservation Working Group, 2007). 
No evidence indicates that the forest is responding to hydrologic and geomorphic changes, but overcup oak regeneration is more common in the Jacks Bay than in the St. Charles and Clarendon reaches. The scarcity of regeneration in those reaches could reduce dominance by overcup oak in the future. Other vegetation changes cannot be ruled out, but there was no obvious signal in the data. Floodplains are highly diverse environments, even within a reach, and factors such as the degree of connectivity to the river, geomorphic surface, and stand disturbance history (as with timber harvesting) create substantial variability. Although we sampled a large number of vegetation plots and cored many trees (relative to similar studies), the sampling effort is probably too small to detect subtle vegetation changes. Furthermore, legacy effects often follow hydrologic and geomorphic changes so that dominant vegetation reflects previous hydrologic and geomorphic conditions rather than current conditions (see Hamilton, 2014). Continued monitoring of vegetation plots, as with current efforts at the White River National Wildlife Refuge, can help identify future vegetation changes. 

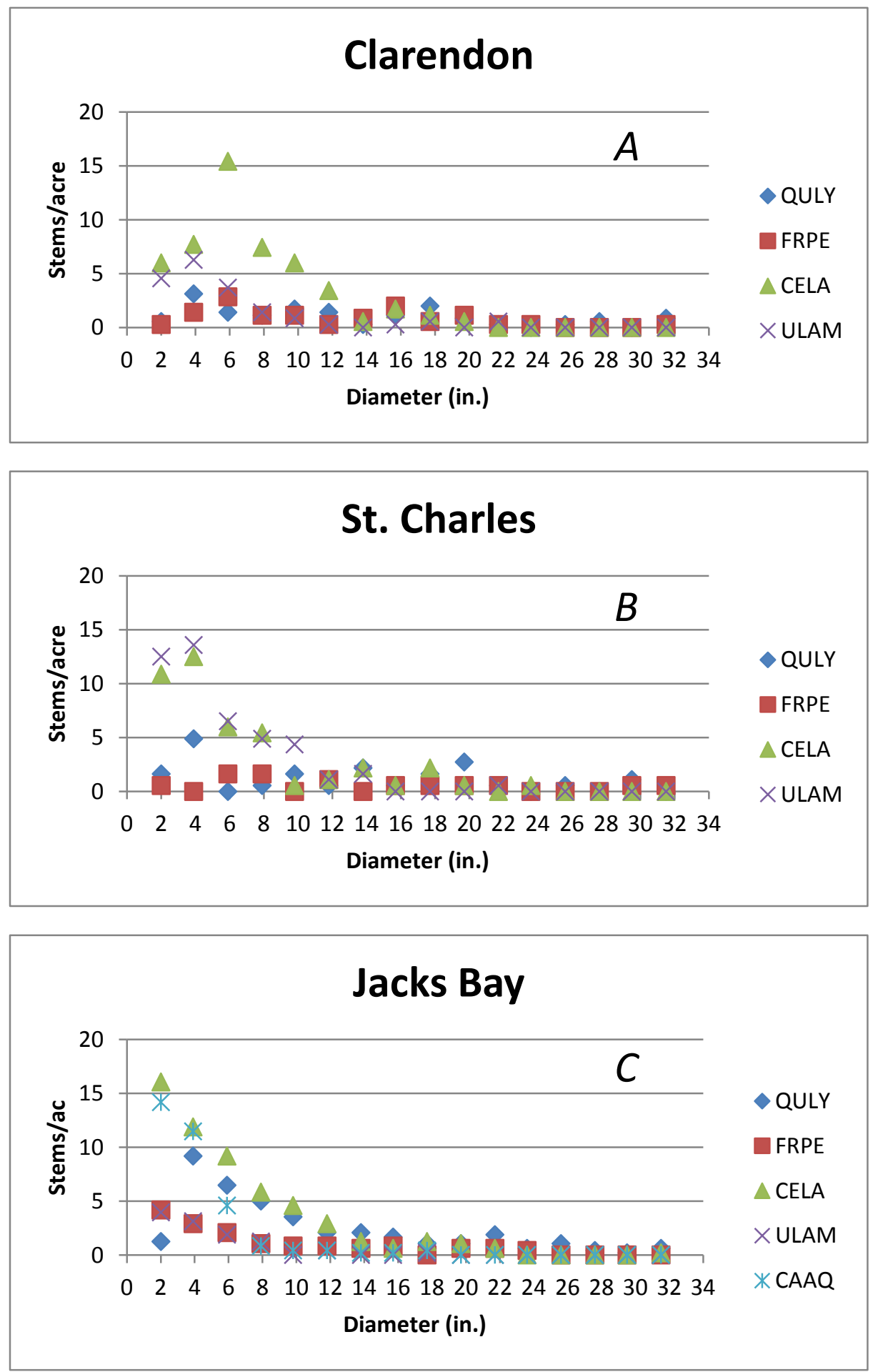

Figure 4.1 Number of trees per acre in each approximate 2.0 inch (in.) diameter class for the most common bottomland hardwood species along the $(A)$ Clarendon, $(B)$ St. Charles, and (C) Jacks Bay reaches of the White River floodplain. Carya aquatica was found in low abundance except on the lower reach. 


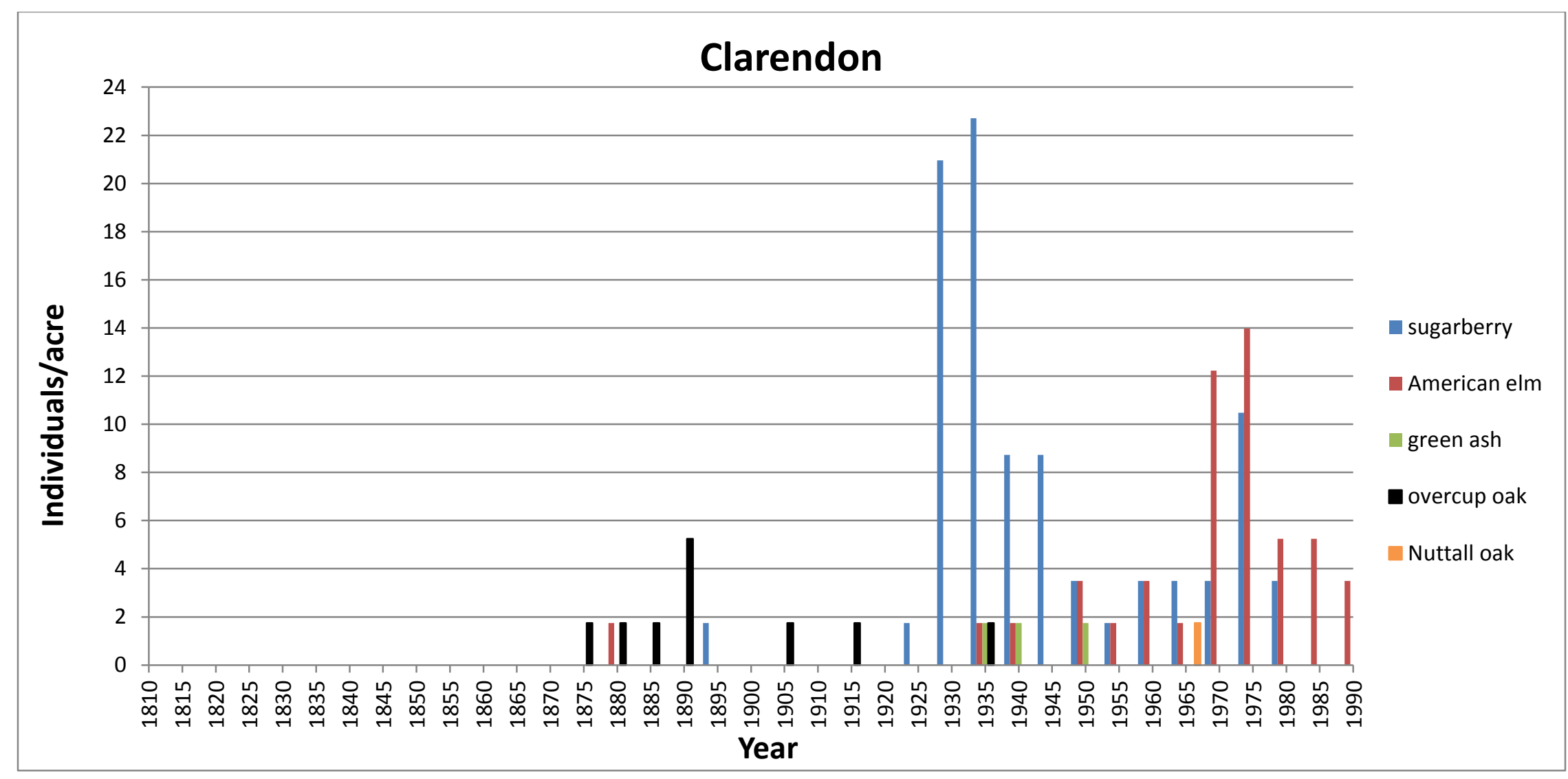

Figure 4.2 Establishment dates of common bottomland hardwood trees cored within the Clarendon reach. 


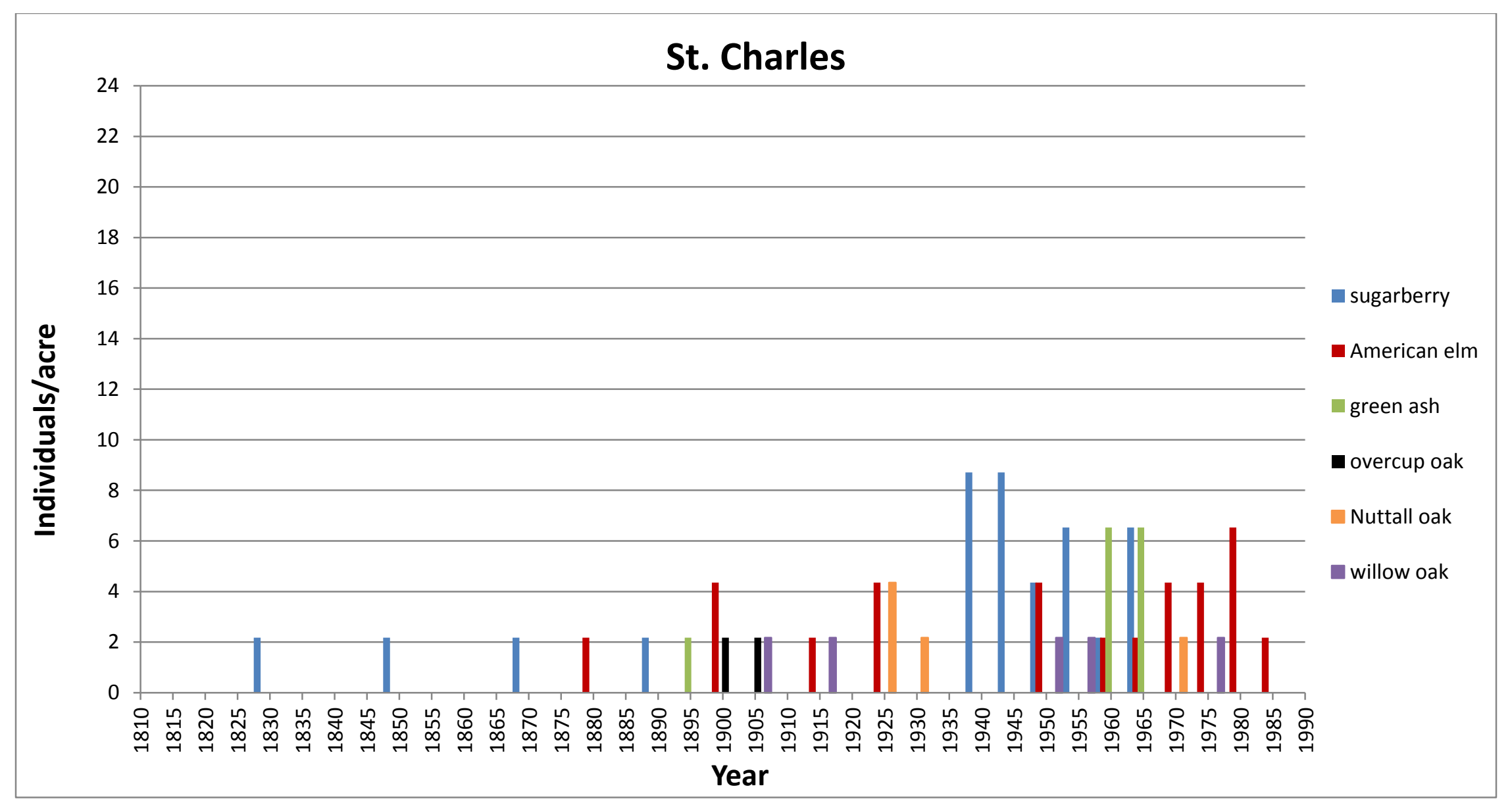

Figure 4.3 Establishment dates of common bottomland hardwood trees cored within the St. Charles reach. 


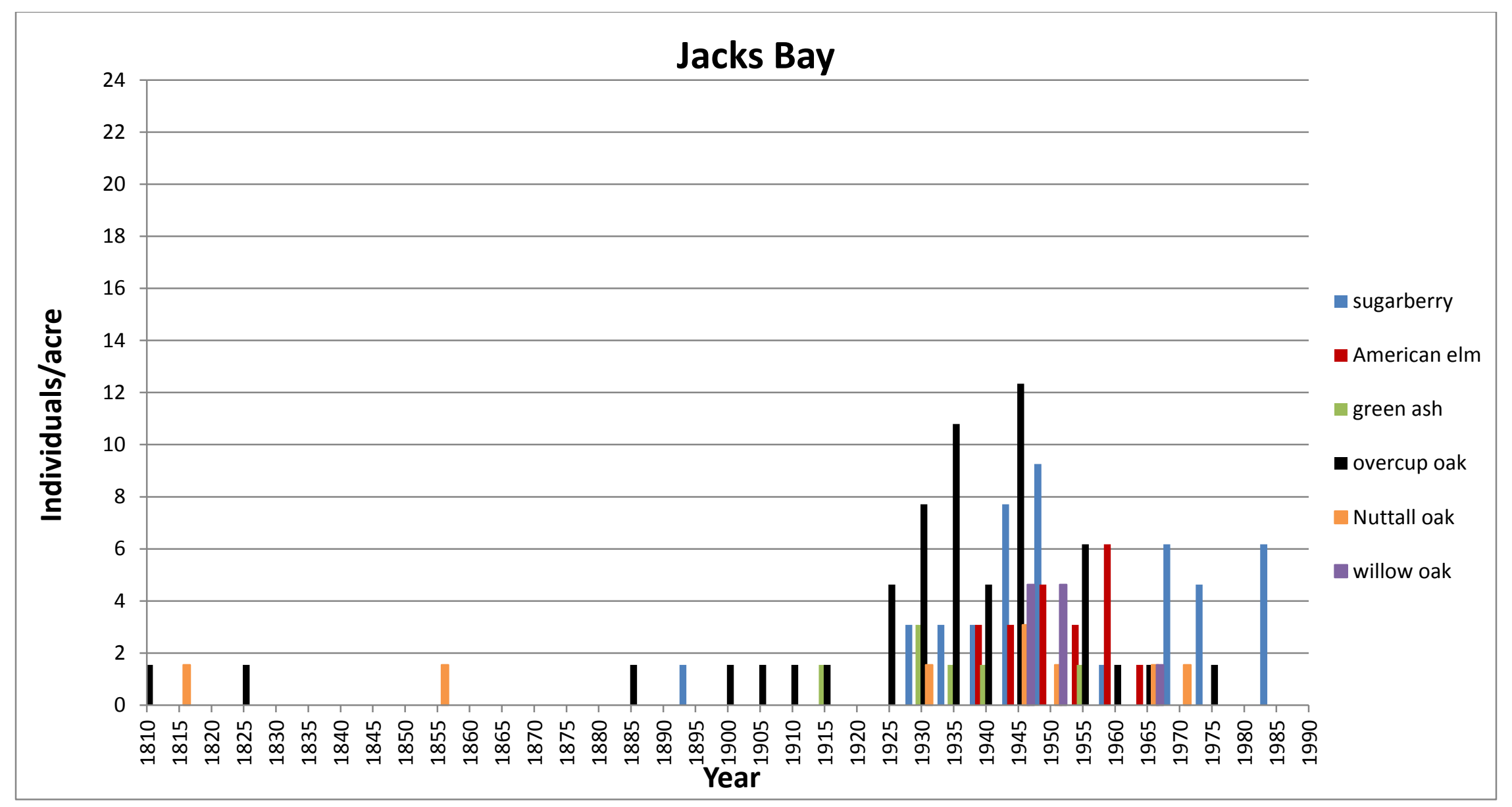

Figure 4.4 Establishment dates of common bottomland hardwood trees cored within the Jacks Bay reach. 


\section{Project Summary and Management Recommendations}

The study area of the White River consists of three geomorphically distinct reaches defined by bed slope and other channel adjustments to anthropogenic-induced change. The dominant geomorphic effect on the river below St. Charles has been incision in response to the incision of the Mississippi River. The dominant geomorphic effect on the river between Clarendon and DeValls Bluff has been channel widening, likely caused by upstream dams. The reach between St. Charles and Clarendon has been least affected by geomorphic change.

Despite the range of errors in modeled flood depths, the parameterization of HEC-RAS was successful in replicating observed water surface slopes but with deviation near St. Charles. The parameterized HEC-RAS model performance was not ideal for estimating impacts on vegetation communities because errors in modeled flood depth were excessive. The origin of these errors is the low resolution DEM available for flood modeling, which failed to reflect the subtle topographic changes that influence spatial variations in flooding and species distribution. The next generation of topographic data and flood modeling are expected to improve resolution substantially.

No conclusive evidence indicates that the forest is responding to hydrologic and geomorphic changes, but overcup oak regeneration is far more common in the Jacks Bay reaches than in the St. Charles and Clarendon reaches. Hydrologic alterations (reduced spring flooding (Gee, 2012)) in those reaches could reduce dominance by overcup oak in the future. Seed germination of overcup oak is enhanced by flooding (Pierce and King, 2007), and lack of flooding leads to increased stem densities (Hanberry and others, 2012), which can further reduce light availability and the regeneration of overcup oak. Other vegetation changes cannot be ruled out, but there was no obvious signal in the data. Some evidence shows that abundant oak regeneration is occurring on the lower White floodplain, which contrasts with other sites in the region that have greater hydrological alterations (for example, Gee and others, 2014).

Although the lowermost reach is incised, Montgomery Point lock and dam could be ameliorating some effects of the incision because it mimics the base level before incision of the Mississippi River. Lacking the artificially high water levels caused by the dam, effective bank heights would be higher and the river level would be farther below the floodplain. Dredging the study area is likely to increase incision and contribute to channel instability. Dredging constitutes artificial base level lowering and sediment deprivation, and these two processes are dominant in existing instability. Altered flows from upstream dams have likely affected the channel banks, and shifts toward more naturally distributed flows would probably improve this problem. Specifically, increased low flows that occurred in the post-dam era contribute to bank collapse, but there are other possible contributors to instability (such as land use or the conditions of tributaries).

Subsurface hydrology in the floodplain remains a significant unknown, especially in the root zone of forests in the incised reach. Hydrologic conditions in the incised reach are linked to river hydrology and were at least locally affected by channel changes (especially incision). Changes in the subsurface hydrology of the floodplain affect productivity and forest species composition. Establishing groundwater monitoring stations could provide useful data for adaptive management of this resource.

Monitoring forest conditions is necessary to identify compositional changes because of time lags and legacy effects in how forests respond to hydrologic and geomorphic changes (Katz and others, 2005; Dufour and Piégay, 2008; Greene and Knox, 2014). Long-lived floodplain tree species can persist for long periods in conditions unsuitable for the regeneration of those species and in conditions that decrease growth. The hydrologic effects of altered flooding and root-zone hydrology might not be apparent until a disruptive event, such as logging or a tornado, affects the forest. 
Monitoring the knickpoint location with bathymetric surveys and bank-height surveys would be key in monitoring geomorphic change. The knickpoint delimits the upper extent of the effect of incision, which is the largest geomorphic change occurring on the river.

The far-ranging impact of backwater flooding on the White River floodplain complicates planning for river management: the White-Arkansas-Mississippi confluence zone is a highly integrated, multi-river system that precludes the isolated management of a single river. Incision rendered the White

River unable, except in rare events, to flood this lower floodplain by means of headwater flooding, so the backwater effect is more important for site hydrology and ecology than in the past. Altering sediment or flow regimes in the Arkansas River is likely to result in extreme changes to this forest.

\section{References}

Allen, S.T., Krauss, K., Cochran, J.W., King, S.L., and Keim, R.F., 2016, Wetland tree transpiration modified by river-floodplain connectivity: Journal of Geophysical Research Biogeosciences v. 121, accessed March 20, 2016, at http://dx.doi.org/10.1002/2015JG003208.

Applequist, M.B., 1958, A simple pith locator for use with off-center increment cores: Journal of Forestry, v. 56, no. 2, p. 141. [Also available at http://www.ingentaconnect.com/content/saf/jof/1958/00000056/00000002/art00013\#expand/collapse.]

Biedenharn, D.S., and Watson, C.C., 1997, Stage adjustment in the lower Mississippi River, USA: Regulated Rivers - Research and Management v. 13, no. 6, p. 517-536, accessed June 16, 2014, at http://dx.doi.org/10.1002/(sici)1099-1646(199711/12)13:6\%3C517::aid-rrr482\%3E3.0.co;2-2.

Casas, A., Benito, G., Thorndycraft, V.R., and Rico, M., 2006, The topographic data source of digital terrain models as a key element in the accuracy of hydraulic flood modelling: Earth Surface Processes and Landforms v. 31, no. 4, p. 444-456, accessed September 4, 2015, at http://dx.doi.org/10.1002/esp.1278.

Craig, M.A., Kitchens, W.E., and Wise, W.R., 2001, Analysis of Hydrologic Data for the White River Basin [Final report, research work order no. 203]: Gainesville, University of Florida, 10 p. [Also available at http://aquaticcommons.org/1001/1/Craig,_M.A._2001.pdf.]

Dufour, S., and Piégay, H., 2008, Geomorphological controls of Fraxinus excelsior growth and regeneration in floodplain forests: Ecology v. 89, no. 1, p. 205-215, accessed May 5, 2015, at http://dx.doi.org/10.1890/06-1768.1.

Gee, Hugo, 2012, The effects of hydrologic modifications on floodplain forest tree recruitment and growth in the Mississippi River Alluvial Valley, USA: Baton Rouge, Louisiana State University, Ph.D. dissertation, 140 p. [Also available at http://etd.lsu.edu/docs/available/etd-04172012145151/unrestricted/geediss.pdf.]

Gee, H.K.W., King, S.L., and Keim, R.F., 2014, Tree growth and recruitment in a leveed floodplain forest in the Mississippi River Alluvial Valley, USA: Forest Ecology and Management, v. 334, p. 85-95. [Also available at http://dx.doi.org/10.1016/j.foreco.2014.08.024.]

Gee, H.K.W., King, S.L., and Keim, R.F., 2015, Influence of hydrologic modifications on Fraxinus pennsylvanica in the Mississippi River Alluvial Valley, USA: Canadian Journal of Forest Research, v. 45, no. 10, p. 1397-1406. [Also available at http://dx.doi.org/10.1139/cjfr-2015-0138.] 
Grams P.E., Schmidt, J.C., and Topping, D.J., 2007, The rate and pattern of bed incision and bank adjustment on the Colorado River in Glen Canyon downstream from Glen Canyon Dam, 1956-2000: Geological Society of America Bulletin v. 119, nos. 5-6, p. 556-575, accessed October 3, 2015, at http://dx.doi.org/10.1130/b25969.1.

Greene, S.L., and Knox, J.C., 2014, Coupling legacy geomorphic surface facies to riparian vegetationAssessing red cedar invasion along the Missouri River downstream of Gavins Point dam, South Dakota: Geomorphology, v. 204, p. 277-286, accessed July 1, 2015, at http://dx.doi.org/10.1016/j.geomorph.2013.08.012.

Hamilton, S.G., 2014, Effect of hydrologic, geomorphic, and vegetative conditions on avian communities in the Middle Rio Grande of New Mexico: Baton Rouge, Louisiana State University, M.S. Thesis. [Also available at http://etd.lsu.edu/docs/available/etd-07112014214309/restricted/S_Hamilton_Thesis.pdf.]

Hanberry, B.B., Kabrick, J.M., He, H.S., and Palik, B.J., 2012, Historical trajectories and restoration strategies for the Mississippi River Alluvial Valley: Forest Ecology and Management, v. 280, p. 103-111, accessed January 27, 2015, at http://dx.doi.org/10.1016/j.foreco.2012.05.033.

Heitmeyer, M.E., and Foti T.L., 2014, Hydrogeomorphic evaluation of ecosystem restoration and management options for Dale Bumpers White River National Wildlife Refuge: Advance, Mo., Greenbrier Wetland Services, Report no. 14-06 (prepared for the U.S. Fish and Wildlife Service Region 4), 80 p. [Also available at https://catalog.data.gov/dataset/hydrogeomorphic-evaluation-ofecosystem-restoration-and-management-options-for-dale-bumper.]

Hupp C.R., 1992. Riparian vegetation recovery patterns following stream channelization: a geomorphic perspective: Ecology v. 73, no. 4, p. 1209-1226, accessed September 2, 2014, at http://dx.doi.org/10.2307/1940670.

Hupp, C.R., and Bornette, Gudrun, 2003. Vegetation, fluvial processes and landforms in temperate areas, chap. 10 in Piegay, Hervé, and Kondolf, G.M., eds., Tools in Geomorphology, Chichester, United Kingdom, Wiley, p. 269-288. [Also available at http://dx.doi.org/10.1002/0470868333.ch10.]

Hupp, C.R., Pierce, A.R., and Noe, G.B., 2009a, Floodplain geomorphic processes and environmental impacts of human alteration along coastal plain rivers, USA: Wetlands v. 292, no. 2, p. 413-429, accessed June 12, 2015, at http://dx.doi.org/10.1672/08-169.1.

Hupp, C.R., Schenk, E.R., Richter, J.M., Peet, R.K., and Townsend, P.A., 2009b, Bank erosion along the dam-regulated lower Roanoke River, North Carolina Geological Society of America, Special Papers, v. 451, p. 97-108, accessed June 12, 2015, at http://dx.doi.org/10.1130/2009.2451(06).

Hupp, C.R., Schenk, E.R., Kroes, D.E., Willard, D.A., Townsend, P.A., and Peet R.K., 2015, Patterns of floodplain sediment deposition along the regulated lower Roanoke River, North Carolina: Annual, decadal, centennial scales: Geomorphology, v. 228, p. 666-680, accessed November 28, 2015, at http://dx.doi.org/10.1016/j.geomorph.2014.10.023.

Katz, G.L., Friedman, J.M., and Beatty, S.W., 2005, Delayed effects of flood control on a flooddependent riparian forest: Ecological Applications, v. 15, no. 3, 1019-1035, accessed February 22, 2015, at http://dx.doi.org/10.1890/04-0076.

Knox, J.C. 2006. Floodplain sedimentation in the Upper Mississippi Valley-Natural versus human accelerated: Geomorphology, v. 79, nos. 3-4, p. 286-310, accessed July 10, 2015, at http://dx.doi.org/10.1016/j.geomorph.2006.06.031. 
Klimas, Charles, Murray, Elizabeth, Foti, Thomas, Pagan, Jody, Williamson, Malcolm, and Langston, Henry, 2009, An ecosystem restoration model for the Mississippi Alluvial Valley based on geomorphology, soils, and hydrology: Wetlands, v. 29, no. 2, p. 430-450, accessed June 25, 2013, at http://dx.doi.org/10.1672/08-99.1.

Leopold, L.B., and Bull, W.B., 1979, Base level, aggradation, and grade: Proceedings of the American Philosophical Society, v. 123, no. 3, p 168-202. [Also available at http://www.jstor.org/stable/986220.]

Ligon, F.K., Dietrich, W.E., and Trush W.J., 1995, Downstream ecological effects of dams: BioScience, v. 45, no. 3, p. 183-192, accessed May 26, 2013, at http://dx.doi.org/10.2307/1312557.

Lower Mississippi Valley Joint Venture Forest Resource Conservation Working Group (LMVJV), 2007, Final Report - Restoration, management, and monitoring of forest resources in the Mississippi Alluvial Valley-Recommendations for enhancing wildlife habitat (version 5.2)(Wilson, Randy; Ribbeck, Kenny; King, Sammy; and Twedt, Dan, eds.): Jackson, Miss., Lower Mississippi River Valley Joint Venture, $137 \mathrm{p}$.

Margolis, E.Q., and Balmat, Jeff, 2009, Fire history and fire-climate relationships along a fire regime gradient in the Santa Fe municipal watershed, NM, USA: Forest Ecology and Management, v. 258, no. 11, p. 2416-2430, accessed March 27, 2015, at http://dx.doi.org/10.1016/j.foreco.2009.08.019.

Musselman, Z.A., 2011, The localized role of base level lowering on channel adjustment of tributary streams in the Trinity River basin downstream of Livingston Dam, Texas, USA: Geomorphology, v. 128 , nos. 1-2, p. 42-56, accessed December 12, 2015, at http://dx.doi.org/10.1016/j.geomorph.2010.12.021.

Nanson, G.C., and Croke, J.C., 1992, A Genetic Classification of Floodplains: Geomorphology, v. 4, no. 6, p. 459-486, accessed January 12, 2015, at http://dx.doi.org/10.1016/0169-555x(92)90039-q.

Nanson, G.C., and Huang, H.Q., 2008, Least action principle, equilibrium states, iterative adjustment and the stability of alluvial channels: Earth Surface Processes and Landforms, v. 33, no. 6, p. 923-942.

Orvis, K.H., and Grissino-Mayer, H.D., 2002, Standardizing the reporting of abrasive papers used to surface tree-ring samples: Tree-Ring Research v. 58, nos. 1-2, p. 47-50. [Also available at http://hdl.handle.net/10150/262564.]

Osterkamp, W.R., and Hupp, C.R., 2010, Fluvial processes and vegetation-Glimpses of the past, the present, and perhaps the future: Geomorphology, v. 116, nos. 3-4, p. 274-285, accessed March 17, 2014, at http://dx.doi.org/10.1016/j.geomorph.2009.11.018.

Phillips, J.D., 2010, The job of the river: Earth Surface Processes and Landforms, v. 35, no. 3, p. 305-313, accessed November 10, 2014, at http://dx.doi.org/10.1002/esp.1915.

Phillips, J.D., Slattery, M.C., and Musselman, Z.A., 2005, Channel adjustments on the lower Trinity River, Texas, downstream of Livingston Dam: Earth Surface Processes and Landforms, v. 30, no. 11, p.1419-1439, accessed January 2, 2015, at http://dx.doi.org/10.1002/esp.1203.

Pierce, A.R., and King, S.L., 2007, The effects of flooding and sedimentation on seed germination of two bottomland hardwood tree species: Wetlands, v. 27, no. 3, p. 588-594. [Also available at http://dx.doi.org/10.1672/0277-5212(2007)27[588:teofas]2.0.co;2.]

Pollock, M.M., Naiman, R.J., and Hanley T.A., 1998, Plant species richness in riparian wetlandsA test of biodiversity theory: Ecology, v. 79, no. 1, p. 94-105, accessed March 3, 2014, at http://dx.doi.org/10.2307/176867. 
Schenk, E.R., and Hupp, C.R., 2009, Legacy Effects of Colonial Millponds on Floodplain Sedimentation, Bank Erosion, and Channel Morphology, Mid-Atlantic, USA: JAWRA Journal of the American Water Resources Association, v. 45, no. 3, p. 597-606, accessed March 4, 2015, at http://dx.doi.org/10.1111/j.1752-1688.2009.00308.x.

Schumm, S.A., and Spitz, W.J., 1996, Geological influences on the Lower Mississippi River and its alluvial valley: Engineering Geology, v. 45, nos. 1-4, p. 245-261, accessed February 22, 2014, at http://dx.doi.org/10.1016/s0013-7952(96)00016-6.

Shaffner, A.L., 2012, Specific gage analysis on the lower White River, Arkansas: Southern Illinois University Carbondale, Illinois, M. S. Thesis. [Also available at http://opensiuc.lib.siu.edu/cgi/viewcontent.cgi?article=2017\&context=theses.]

Simon, Andrew, and Hupp, C.R., 1992, Geomorphic and vegetative recovery processes along modified stream channels of West Tennessee: U.S. Geological Survey Open-File Report 91-502; 142 p., accessed January 12, 2015, at https://pubs.er.usgs.gov/publication/ofr91502.

Simon, Andrew, and Rinaldi, Massimo, 2006, Disturbance, stream incision, and channel evolutionThe roles of excess transport capacity and boundary materials in controlling channel response: Geomorphology, v. 79, nos. 3-4, p. 361-383, accessed December 2, 2014, at http://dx.doi.org/10.1016/j.geomorph.2006.06.037.

Stokes, M.A., and Smiley, T.L., 1996, An introduction to tree-ring dating: Tucson, AZ, University of Arizona Press, 73 p.

United States Forest Service, 2011, Forest Inventory and Analysis National Core Field Guide Volume I: Field Data Collection Procedures for Phase 2 Plots Version 5.1

U.S. Army Corps of Engineers, 1939, 15-minute series maps [Arkansas and Mississippi]: Vicksburg, Miss., Mississippi River Commission, accessed May 27, 2016, at https://www.sciencebase.gov/catalog/folder/4f4fede8e4b0bac7385da2ea.

U.S. Department of Agriculture, 1937-1954, Indexes to aerial photography of Prairie County, Arkansas: Washington, D.C., National Archives at College Park-Cartographic (RDSC), scale 1:20,000. [Media data accessible at https://research.archives.gov/id/1137013.]

U.S. Department of Agriculture, 1937-1954, Indexes to aerial photography of Monroe County, Arkansas: Washington, D.C., National Archives at College Park-Cartographic (RDSC), scale 1:20,000. [Media data accessible at https://research.archives.gov/id/1137213.]

U.S. Department of Agriculture, 1937-1954, Indexes to aerial photography of Phillips County, Arkansas: Washington, D.C., National Archives at College Park-Cartographic (RDSC), scale 1:20,000. [Media data accessible at https://research.archives.gov/id/1137228.]

U.S. Department of Agriculture, 1937-1954, Indexes to aerial photography of Prairie County, Arkansas: Washington, D.C., National Archives at College Park-Cartographic (RDSC), scale 1:20,000. [Media data accessible at https://research.archives.gov/id/1137360.]

U.S. Geological Survey, 2012, Map locator \& downloader, The USGS Store: U.S. Geological Survey Web page, accessed June 02, 2016, at http://store.usgs.gov/b2c_usgs/usgs/maplocator.do.

U.S. Geological Survey, 2015a, Digital orthophoto quadrangles, Long term archive products [Arkansas and Mississippi]: U.S. Geological Survey Long Term Archive, accessed May 27, 2016, at https://lta.cr.usgs.gov/products_overview/. 
U.S. Geological Survey, 2015b, Long term archive products [Arkansas and Mississippi]: U.S. Geological Survey Long Term Archive, accessed May 27, 2016, at https://lta.cr.usgs.gov/products_overview/.

U.S. Geological Survey, 2015c, National Agriculture Imagery Program [Arkansas and Mississippi], Long term archive products: U.S. Geological Survey Long Term Archive, accessed May 27, 2016, at https://lta.cr.usgs.gov/products overview/.

U.S. Geological Survey, 2016, Historical topographic map collection [Arkansas and Mississippi]:

U.S. Geological Survey TopoView Collection, accessed June 02, 2016, at http://ngmdb.usgs.gov/maps/TopoView/.

Williams GP, MG Wolman, 1984, Downstream effects of dams on alluvial rivers. U.S. Geological Survey Professional Paper 1286, 83 p., accessed December 1, 2014, at https://pubs.er.usgs.gov/publication/pp1286.

Yamaguchi, D.K., 1991, A simple method for cross-dating increment cores from living trees: Canadian Journal of Forest Research, v. 21, no. 3, p. 414-416, accessed November 12, 2014, at http://dx.doi.org/10.1139/x91-053. 

ISSN 2331-1258 (online)
http://dx.doi.org/10.3133/ofr20161113 